OPEN ACCESS

Edited by:

Carsten Watzl

Leibniz Research Centre for Working

Environment and Human Factors

(IfADo), Germany

Reviewed by:

Arnika Kathleen Wagner,

Karolinska Institute, Sweden

Francisco Borrego,

BioCruces Health Research

Institute, Spain

*Correspondence:

Domingo F. Barber

dfbarber@cnb.csic.es

†These authors have contributed equally to this work

¥Present address:

José M. Rojas,

Animal Health Research Centre

(CISA)-INIA, Instituto Nacional de Investigación y Tecnología Agraria y Alimentaria, Madrid, Spain

Specialty section:

This article was submitted to NK and Innate Lymphoid Cell Biology,

a section of the journal

Frontiers in Immunology

Received: 10 June 2019 Accepted: 16 August 2019

Published: 30 August 2019

Citation:

Sanz-Ortega L, Rojas JM, Portilla Y, Pérez-Yagüe S and Barber DF (2019) Magnetic Nanoparticles Attached to

the NK Cell Surface for Tumor Targeting in Adoptive Transfer Therapies Does Not Affect Cellular Effector Functions.

Front. Immunol. 10:2073.

doi: 10.3389/fimmu.2019.02073

\section{Magnetic Nanoparticles Attached to the NK Cell Surface for Tumor Targeting in Adoptive Transfer Therapies Does Not Affect Cellular Effector Functions}

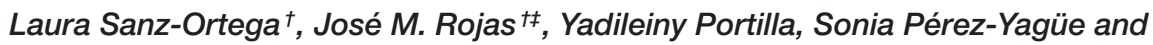 \\ Domingo F. Barber*
}

Department of Immunology and Oncology, and NanoBiomedicine Initiative, Centro Nacional de Biotecnología (CNB)-CSIC, Madrid, Spain

Adoptive cell transfer therapy is currently one of the most promising approaches for cancer treatment. This therapy has some limitations, however, such as the dispersion of in vivo-administered cells, causing only a small proportion to reach the tumor. Nanotechnological approaches could offer a solution for this drawback, as they can increase cell retention and accumulation in a region of interest. In particular, strategies employing magnetic nanoparticles (MNPs) to improve targeting of adoptively transferred $\mathrm{T}$ or NK cells have been explored in mice. In vivo magnetic retention is reported using the human NK cell line NK-92MI transfected with MNPs. Primary NK cells are nonetheless highly resistant to transfection, and thus we explore in here the possibility of attaching the MNPs to the NK cell surface to overcome this issue, and examine whether this association would affect NK effector functions. We assessed the attachment of MNPs coated with different polymers to the NK cell surface, and found that APS-MNP attached more efficiently to the NK-92Ml cell surface. In association with MNPs, these cells preserved their main functions, exhibiting a continued capacity to degranulate, conjugate with and lyse target cells, produce IFN- $\gamma$, and respond to chemotactic signals. MNP-loaded NK-92Ml cells were also retained in an in vitro capillary flow system by applying an EMF. A similar analysis was carried out in primary NK cells, isolated from mice, and expanded in vitro. These primary murine NK cells also maintained their functionality intact after MNP treatment and were successfully retained in vitro. This work therefore provides further support for using MNPs in combination with EMFs to favor specific retention of functional NK cells in a region of interest, which may prove beneficial to adoptive cell-therapy protocols.

Keywords: cell-based therapy, NK cell, magnetic nanoparticle, magnetic retention, cancer immunotherapy

\section{INTRODUCTION}

Cancer is one of the leading causes of death in our society, and developing successful therapies to halt cancer progression is a central goal around the world. Currently, immunotherapy, and in particular adoptive transfer therapy, is one of the most promising approaches to treat cancer. NK cells play an essential role in host immunity to cancer and as such are ideal candidates for adoptive 
transfer. First identified in the 1970s by Kiessling, NK cells are a subpopulation of lymphocytes that are larger in size than $\mathrm{T}$ and $\mathrm{B}$ lymphocytes and are capable of eliminating tumor cells without prior sensitization (1-3).

Resting NK cells constitute 10-15\% of the circulating lymphocytes in peripheral blood, and activation by cytokines and chemokines induces the extravasation and recruitment of these cells to tumor or inflamed tissues (4). This activation of NK effector functions is modulated by a balance between signals transmitted by the inhibitory and activating receptors present on the cell surface. NK cells remain inactive when they encounter normal or healthy cells that express MHC class I molecules, which interact with the inhibitory receptors, and barely express ligands for NK-activating receptors. However, their cytotoxic potential is released when a malignant cell shows an altered or reduced MHC class I profile together with high expression of activating ligands (5). NK cells can also modulate the activity of different immune-cell types within the tumor microenvironment by direct contact or through the release of cytokines or chemokines (6), such as IFN- $\gamma$ or TNF $\alpha$, that can amplify and recruit an inflammatory response through various mechanisms $(7,8)$. They are a major source of IFN- $\gamma$ in vivo, considered crucial to inhibit tumor angiogenesis and in the modeling of adaptive immunity $(9,10)$.

There is ample evidence supporting the importance of NK cells in antitumor immunity. NK cell depletion in murine tumor models of allogeneic transplantation has established the crucial role of NK cells in the control of tumor growth and metastasis $(11,12)$. NK cell infusions into mice lacking this cell type generated resistance against the formation of metastasis (12). Allogenic or autologous human NK cells can recognize and eliminate patient biopsy-derived tumor cells in vitro. High levels of intratumoral NK cells correlate with greater survival in several malignancies such as colorectal, gastric, or esophageal cancer (13-16). Tumor cell recognition is likely based on a combination of NK cell activation by activating receptor (NKG2D, DNAM-1, NKp30, NKp44), a low expression of MHC class I on tumor cells, and mismatched KIR ligands for the graft vs. hematological malignancy effects (14-17). An 11-year prospective study has correlated the high and moderate cytotoxic activity of peripheral blood NK cells with a lower risk of developing cancer, providing further evidence of the role of NK cells in tumor immunovigilance (17). These studies highlight the beneficial role of NK cells in cancer prognosis and their potential use to treat cancer.

Since NK cells do not depend on the existence of a tumor antigen or previous activation, and are easy to obtain through peripheral blood, they represent an attractive reagent for immunotherapy. NK cells speed of action, power, broad specificity, the absence of side effects, and the fact that they can complement other therapeutic approaches such as chemo/radiotherapy make them particularly suited for adoptive therapy. Ruggeri et al. demonstrated the potent clinical effect of alloreactive NK cells in patients with AML (18), while Miller et al. demonstrated that transfer of haploidentical NK cells expanded in patients with advanced cancer together with subcutaneous IL-2 is a safe treatment (19).
Adoptive transfer of NK cells requires a large number of cells, which are usually obtained from peripheral blood and expanded ex vivo. NK cells can also be generated from haematopoietic stem cells from the umbilical cord (20) or from embryonic or pluripotent stem cells (21). Furthermore, the use of purified NK cell lines such as the NK-92 line, which is derived from clones of malignant NK cells, is being explored widely. The NK-92 cell line is an IL-2-dependent NK human cell line that was established in 1992 using the peripheral blood of a non-Hodgkin's lymphoma patient $(22,23)$. This human NK cell line is characterized by the expression of CD56 and the absence of CD16, and therefore, of ADCC. NK-92 cells lack almost all KIR inhibitory receptors (24) and express the activating receptors NKG2D, NKp30 and NKp46, but not NKG2C or NKp44 $(24,25)$. This NK cell line has superior cytotoxicity against multiple targets compared to primary or traditional NK cells $(23,26-28)$, probably due to the apparent lack of inhibitory receptors and the presence of high levels of perforin and granzyme B. Its cytotoxicity has been demonstrated both in vitro (23) and in vivo in human melanoma and leukemia xenotransplants $(26,27)$. In addition, this cell line is attracting much attention due to the ease with which it can be cultured and genetically modified when compared to primary NK cells. For instance, NK-92 cell modification with CARs are being explored as routes to overcome escape mechanisms and redirect more specifically their NK cell activity $(29,30)$. Several ongoing clinical trials have already proved NK-92 safety in these settings (31).

In spite of its promise, NK cell adoptive transfer has only achieved modest results at the clinical level (32). Transferred autologous NK cells can occasionally express low levels of activation markers or activating receptors such as NKG2D. Additionally, in vivo-administered NK cells tend to disperse throughout the organism such that only a small proportion reach the tumor. The combination of these two factors makes for inefficient tumor elimination (33). Therefore, much effort is being made to understand the molecular mechanisms that govern the maturation of NK cells and their effector activity against tumor cells, which will help to design optimal protocols for the therapeutic application of NK cells (34). Similarly, the design of strategies that facilitate accumulation of NK cells in the tumor area will enable the development of more efficient antitumor therapies (35). Nanotechnology has proven very useful in selectively directing drugs or molecules to a target site, and this knowledge could be used to develop more effective treatment protocols. One promising strategy consists of magnetically targeting these administered NK cells through the combination of MNPs and EMFs so they may be concentrated in the region of interest. This approach has been used to accumulate stem cells, mesenchymal cells, macrophages, and dendritic cells in tissueregeneration therapies and for the treatment of autoimmune disorders $(29,36-40)$, though it has seen very limited application in redirecting lymphoid cells such as $\mathrm{T}$ or NK cells to treat cancer $(29,30)$. Indeed, there is only one report in which MNPs were magnetically transfected into the human NK-92MI cell line, allowing tumor-targeting of MNP-loaded NK cells using an external magnet (30). Primary NK cells are notoriously difficult to transfect and typically require cytokine stimulation 
or pattern recognition receptor (PRR) signaling inhibition to be effective $(41,42)$, suggesting that MNP loading through magnetic transfection could be problematic in primary cells. Previous results in our lab have shown that APS-MNPs can be attached to the cytoplasmic membrane of primary murine $\mathrm{T}$ cells, and that these nanoparticles enable specific targeting and retention of the modified T cells to lymph nodes using magnets (43).

To determine whether specific magnetic retention of completely functional NK cells could be achieved, we assess magnetic nanoparticles attachment to the NK cell surface and the targeting and retention of the modified NK cells through the application of an EMF. We also examine whether this modification alters functional aspects of NK cell biology. To do this, we first used the prototypic NK cell line NK-92MI, which had been magnetically transfected in another report (30), to evaluate the feasibility of attaching nanoparticles on the surface of cells instead of transfecting them. NK-92MI cells are derived from NK-92 cells, which originated from a patient with granular lymphoma and displays great cytotoxicity for a variety of tumor lines (44-46), including the human K562 cell line (47). NK-92 cells are the only NK cell line approved by the FDA for use in clinical trials and was shown to be safe to use as cell transfer in humans $(26,48,49)$. NK-92MI cells were obtained by transfection of the IL-2-encoding gene, and as a result their growth is independent of IL-2 $(50,51)$. This variant is identical to parental cells in nearly all aspects and their use could allow prolonged treatment with active NK cells without the necessity for exogenous IL-2 $(50,51)$.

We also carried out a similar analysis in primary murine NK cells as a model. The results showed that the human NK92MI cell line and the primary murine NK cells preserved their functionality in the presence of MNP attached to the cell surface. Both NK cell models loaded with MNPs were also retained in an in vitro capillary flow system by using a magnet.

This work details an interesting and simple approach which could be used to improve NK cell migration to a region, thereby increasing the number of cytolytic NK cells with intact functionality that reach the tumor, leading to more efficient treatment.

\section{MATERIALS AND METHODS MNP Synthesis and Physico-Chemical
Characterization}

The synthesis and characterization of the different MNPs used in this study have been described previously (43). Briefly, iron-oxide cores were synthesized by following the Massart co-precipitation protocol (52), and these iron cores were then coated with dimercaptosuccinic acid (DMSA), (3aminopropyl) triethoxysilane (APS), or dextran $6 \mathrm{kDa}$ (DEXT) in accordance with the previously described procedures (53). Next, we performed a physico-chemical characterization of the different coated MNPs. The hydrodynamic diameter and Z-potential were measured by dynamic light scattering, and the presence as well as the percentage of coating molecules on the MNP surface were analyzed by infrared spectroscopy and thermogravimetric analyses, respectively. MNP morphology was studied by transmission electronic microscopy (TEM) and their magnetic properties were analyzed in a vibrating sample magnetometer.

\section{Cell Culture}

The human NK-92MI cell line (kindly provided by Dr. A. PérezMartínez, IdiPaz, Madrid, Spain) was cultured in RPMI1640 supplemented with 5\% FBS, 5\% human serum (Sigma-Aldrich), $2 \mathrm{mM}$ L-glutamine, $100 \mathrm{U} / \mathrm{ml}$ penicillin/streptomycin (P/S), $1 \mathrm{mM}$ sodium pyruvate, $50 \mu \mathrm{M}$ 2-mercaptoethanol, $10 \mathrm{mM}$ HEPES, $1 \mathrm{X}$ non-essential amino acids (complete RPMI medium), and 50-100 U/ml recombinant human IL-2 (Peprotech) when required, under standard culture conditions $\left(37^{\circ} \mathrm{C}, 5 \% \mathrm{CO}_{2}, 90 \%\right.$ relative humidity). The murine tumor cell lines YAC-1 (ATCC: TIB-160) and RMA/S (courtesy of Dr. B. Chambers, Karolinska Institute, Sweden) as well as the human tumor cell line K562 (provided by Dr. A. Pérez-Martínez, IdiPaz, Spain) were cultured in RPMI1640 with $10 \%$ FBS, 2 mM L-glutamine, and $100 \mathrm{U} / \mathrm{ml}$ $\mathrm{P} / \mathrm{S}$. The murine endothelial cell line SVEC4-10 (ATCC: CRL2181) was cultured in DMEM with $10 \%$ FBS, 2 mM L-glutamine, $1 \mathrm{mM}$ sodium pyruvate, and $100 \mathrm{U} / \mathrm{ml} \mathrm{P} / \mathrm{S}$. Cells were cultured under standard conditions at all times.

Murine NK cells were purified from the spleens of $12-$ 20 weeks old C57BL/6 mice (Jackson Laboratories). These spleens were processed to obtain the cell suspension following erythrocyte lysis. We then used the positive selection AntiNKp46 Microbead Kit (mouse) (Miltenyi Biotec) to isolate murine NK cells, following the manufacturer's instructions. Once isolated, they were cultured in 96-well U-bottom culture plates using the complete RPMI medium supplemented with murine recombinant IL-2 (1,000 U/ml, Peprotech) and expanded for 7 days. The percentage of NK cells $\left(\mathrm{CD}^{-} \mathrm{NKp}^{-} 6^{+}\right)$was checked by flow cytometry at day 0 and day 7 , obtaining a purity of around $90-95 \%$ after expansion. At this point they were used in the corresponding experiments.

\section{Mice}

C57BL/6 mice were purchased from Jackson Laboratories, housed in the CNB animal facility, and handled according to the recommendations of the CNB-CSIC institutional ethics committee. Procedures involving animals were approved by the CSIC ethics committee for animal experimentation and by the Division of Animal Protection of the regional government of Madrid in compliance with national and European Union legislation.

\section{Cell Viability}

Cell viability was studied by Alamar Blue assay (Invitrogen) and FITC-annexin V/propidium iodide staining. In the former, either the murine NK cells expanded in vitro in the presence of IL-2 or NK-92MI cells were incubated with different MNP concentrations for $24 \mathrm{~h}$, after which Alamar Blue was added and then cultured for an additional $4 \mathrm{~h}$, at which point fluorescence was measured. For the second assay, cells were processed using the Annexin V-PI apoptosis assay kit following the 
manufacturer's protocol (Life Technologies) and analyzed by flow cytometry.

\section{MNP Uptake and Release}

To quantify MNP uptake by inductively coupled plasma-optical emission spectrometry (ICP-OES), murine NK cells expanded in vitro in the presence of IL-2 or the human NK-92MI cell line $\left(10^{7}\right.$ cells $\left./ \mathrm{ml}\right)$ were treated with MNPs $(150 \mu \mathrm{g} \mathrm{Fe} / \mathrm{ml})$ for $2 \mathrm{~h}$, after which they were washed to eliminate the excess of MNPs and digested at $90^{\circ} \mathrm{C}$ with $\mathrm{HNO}_{3} 63 \%$ and then with $\mathrm{H}_{2} \mathrm{O}_{2}$.

To evaluate the MNP release from cells, the human NK-92MI cell line $\left(10^{7} \mathrm{cells} / \mathrm{ml}\right)$ were treated with MNPs $(150 \mu \mathrm{g} \mathrm{Fe} / \mathrm{ml})$ for $2 \mathrm{~h}$, after which they were washed to eliminate the excess of MNPs and cultured in $1 \mathrm{ml}$ medium for several timepoints (24, 48 and $72 \mathrm{~h}$ ). At these timepoints, the supernatant was collected, digested at $90^{\circ} \mathrm{C}$ with $\mathrm{HNO}_{3} 63 \%$ and then with $\mathrm{H}_{2} \mathrm{O}_{2}$ and the presence of iron was measured by ICP-OES.

\section{Microscopy Analysis}

For confocal microscopy, we stained the in vitro-expanded murine NK cells or the human NK-92MI cell line after MNP treatment with LysoTracker Red DND-99 (Life Technologies), Alexa Fluor 647-wheat-germ agglutinin (Life Technologies), and DAPI. Finally, the samples were mounted in FluoromountG (Southern Biotec), and images were acquired using a confocal multispectral Leica TCS SP5 system with a $63 \times / 1.4$ NA oil-immersion objective. To visualize the MNPs, dark-field microscopy was used. For TEM, expanded murine NK cells or the human NK-92MI cell line, some treated with MNPs and some without treatment, were fixed and processed by the Transmission Electron Microscopy Service at the National Center for Biotechnology (CNB-CSIC, Madrid, Spain). Images were acquired with a JEOL JEM 1,011 transmission electron microscope at various magnifications.

\section{Flow Cytometry and Proliferation Assays}

The following primary anti-mouse antibodies were used: antiNK1.1 (PK136), -CD69 (H1.2F3), -CD62L (Mel-14), -Ly49A+D (12A8), and -Ly49D (4E5) from Pharmingen, -CD3 (17A2, eBioscience), -NKp46 (29A.1, Biolegend), -NKG2D (CX5, Invitrogen), -CD27 (LG.3A10, BD), -CD11b (M1/70, Beckman C.), and -Ly49F (HBF-719, Coulter). The following primary anti-human antibodies were used: anti-CD56 (N901 (NKH1)), -CD95 (7C11), -HLA-ABC (B9.12.1), -CD27 (1A4CD27), -CD11b (BEAR-1) and -CD11a (25.3.1) from Immunotech, NKp46 (9E2), -KLRG1 (SA231A2), and -DNAM-1 (11A8) from Biolegend, -CD16 (3G8) and -CD25 (B1.49.9) from Beckman C., -CD69 (FN50, eBioscience), -NKG2D (1D11, BD), and IFN- $\gamma$ (B27, Pharmingen). Data were acquired on a FC500 flow cytometer and analyzed with FlowJo software.

For intracellular protein labeling, cells were permeabilized by washing them with a $0.5 \%$ saponin in PBS staining buffer. Then, they were subsequently labeled with the corresponding antibodies, which had been diluted in this solution, for $30 \mathrm{~min}$ at $4^{\circ} \mathrm{C}$. The cells were then washed two times with PBS and resuspended in PBS for analysis by flow cytometry.
For proliferation assays, NK-92MI cells were labeled with the CellTrace CFSE cell proliferation kit (Thermofisher) as described in Rojas et al. (54). Cell were loaded with $150 \mu \mathrm{g} / \mathrm{mL}$ APS-MNP (or left untreated as control) and proliferation evaluated after 0 , 48 and $96 \mathrm{~h}$.

\section{Conjugation Assays}

Either murine NK cells expanded in vitro in the presence of IL-2 or the human NK-92MI cell line, treated with APS-MNPs or not, as well as the corresponding cellular targets (murine RMA/S and YAC-1 cell lines for murine NK cells and the human K562 cell line for NK-92MI cells) were stained using the fluorescent labeling kits, consisting of dyes for red (PKH26) or green (PKH67) (both from Sigma-Aldrich), alternating labeling between the effector and target cells in the different experiments. Murine or human NK cells and their corresponding target cells were coincubated for varying periods of time at a 1:1 ratio under standard incubation conditions, after which they were fixed in 1\% PFA and analyzed by flow cytometry. Each procedure was performed in duplicate. The events positive for both colors were considered to be conjugated between the NK cell and its target, and the percentage of conjugated NK cells was calculated as follows: (\% conjugated NK cells / $\%$ total NK cells) $\times 100 \%$.

\section{Degranulation Assays}

We incubated $2 \times 10^{5}$ murine NK cells expanded in vitro in the presence of IL-2 or the human NK-92MI cell line, treated with APS-MNPs or not, with different stimuli and in the presence of $10 \mu \mathrm{g} / \mathrm{ml}$ of monensin (Sigma-Aldrich) and $5 \mu \mathrm{l}$ of the CD107a antibody conjugated with FITC (or its corresponding control). After $4-5 \mathrm{~h}$ of incubation under standard conditions, CD3 and NKp46 (murine) or CD56 (human) markers were labeled for cytometry. The percentage of $\mathrm{CD}^{-}{ }^{-} \mathrm{NKp} 46^{+} \mathrm{CD} 107 \mathrm{a}^{+}$cells (for murine NK cells) or $\mathrm{CD} 6^{+} \mathrm{CD} 107 \mathrm{a}^{+}$cells (for human NK-92MI cells) was analyzed by flow cytometry.

A variety of stimuli were used in these assays. Murine NK cells expanded in vitro in the presence of IL-2 were seeded in 96-well plates previously coated with the antibody antimouse NKG2D (10 $\mu \mathrm{g} / \mathrm{ml}$; A10, eBioscience), or -mouse NKp46 $(5 \mu \mathrm{g} / \mathrm{ml} ; 29 \mathrm{~A} 1.4$, Biolegend), or -mouse NK1.1 $(10 \mu \mathrm{g} / \mathrm{ml}$; PK136, Biolegend), or the appropriate controls. NK-92MI cells were co-cultured with K562 cells at a 1:2 ratio (NK-92MI cells: K562 cells) or seeded in 96-well plates previously coated with the anti-human NKG2D antibody (10 $\mathrm{gg} / \mathrm{ml}$; 1D11, Pharmingen). Besides, brefeldin A or monensin were also added during the stimulation to inhibit protein transport and to detect intracellular CD107a marker.

\section{Cytolytic Activity Measurements}

Expanded murine NK cells or the human NK-92MI cell line, treated with APS-MNPs or not, were co-incubated with their corresponding targets (murine RMA/S and YAC-1 cell lines for murine NK cells and the human K562 cell line for NK-92MI cells), which had been previously stained with the PKH67 Green fluorescent cell-linker kit (Sigma-Aldrich) at different ratios in a total volume of $200 \mu \mathrm{l}$ for $4 \mathrm{~h}$ under standard incubation conditions and in 96-well U-bottom plates. Each procedure was 
performed in duplicate. The reaction was stopped by adding $250 \mu \mathrm{l}$ of cold PBS staining, and the plates were placed in ice. Fifteen microliter of PI were added to each well just before flow cytometry analysis. The percentage of specific lysis was calculated for each target cell as follows: \% lysis = (\% dead target cells- $\%$ spontaneous death) / (100-\% spontaneous death) $\times 100 \%$. The percentage of spontaneous death was calculated in the absence of effector cells.

\section{Intracellular Staining of IFN- $\gamma$}

NK-92MI cells treated with APS-MNPs or not were exposed to different stimuli to determine their IFN- $\gamma$ production capacity by analyzing intracellular IFN- $\gamma$ levels using flow cytometry. To do this, $2 \times 10^{5}$ effector cells were incubated with certain stimuli or specific targets in the presence of brefeldin A (1X, Biolegend). After $4-5 \mathrm{~h}$ of incubation under standard conditions, they were labeled for CD3 and NKp46, at which point intracellular staining was carried out. The percentage of $\mathrm{CD} 56^{+} \mathrm{IFN}-\gamma^{+}$cells was analyzed by flow cytometry.

The different stimuli used in these assays were the following: co-incubation with K562 cells at a 1:2 ratio (NK-92MI cells: K562 cells) or $25 \mathrm{ng} / \mathrm{ml}$ PMA and $1 \mu \mathrm{g} / \mathrm{ml}$ ionomycin, both from Sigma-Aldrich. In addition, brefeldin A or monensin were also added during the stimulation to inhibit protein transport and to detect intracellular IFN- $\gamma$.

\section{ELISA (IFN- $\gamma$ )}

The supernatants obtained during the degranulation experiment performed with the in vitro-expanded murine NK cells were collected and the production of IFN- $\gamma$ (produced by the NK cells) was analyzed by the commercial ELISA kit BD OptEIA Mouse IFN- $\gamma$ ELISA Set following the manufacturer's instructions.

\section{Adhesion and Transmigration Capacity Evaluation}

We seeded 3-4 $\times 10^{4}$ murine endothelial cells (SVEC4-10 cells) on coverslips with a $12-\mathrm{mm}$ diameter, placing these in a 24-well culture plate. These were then cultured under standard conditions until the monolayer was formed, after which the monolayer was activated with murine TNF $\alpha(250 \mathrm{U} / \mathrm{ml}$, Peprotech) for $6 \mathrm{~h}$. In addition, murine NK cells expanded in vitro in the presence of IL-2 were labeled with the CellTrace CFSE probe $(2.5 \mu \mathrm{M}$, ThermoFisher Scientific) following the manufacturer's instructions. Once labeled, they were incubated with different concentrations of APS-MNPs for $2 \mathrm{~h}$ under standard conditions, after which $5 \times 10^{4}$ cells were seeded on the activated endothelium monolayer and incubated for $1 \mathrm{~h}$. Subsequently, the cells over the monolayer were washed with PBS, fixed with 4\% PFA for $20 \mathrm{~min}$, and the actin filaments were stained with phalloidin-TRITC (1: 500, Sigma-Aldrich) for $45 \mathrm{~min}$ at RT in the dark. Finally, the cells were washed with PBS and mounted on slides with Fluoromount-G for observation by confocal microscopy. The images were acquired with the Leica TCS SP5 confocal microscope, using the $10 \times$ and $20 \times$ lenses, sweeping the entire monolayer in $1-\mu \mathrm{m}$ slices. The images obtained were analyzed by ImageJ software.

\section{Flow Chamber Assays}

In vitro magnetic retention assays were carried out under flow conditions in a modified channel slide ( $\mu$-Slide I Luer, 0.4-mm height, ibidi) using a two-magnet system as previously described (43). The neodymium iron boron $(\mathrm{NdFeB})$ permanent magnets (Supermagnete) used in this study were the following: an 5 $\times 14-\mathrm{mm}$ magnet with $1.35 \mathrm{~T}$ of remanent magnetization $(\mathrm{Br})$ (magnet $\mathrm{A}$ ) and an $8 \times 6$-mm magnet with $1.45 \mathrm{~T}$ of remanent magnetization (Br) (magnet B). Briefly, either murine NK cells expanded in vitro in the presence of IL-2 or the human NK-92MI cell line $\left(10^{7}\right.$ cells $\left./ \mathrm{ml}\right)$ were treated with MNPs $(150 \mu \mathrm{g} \mathrm{Fe} / \mathrm{ml})$ or not for $2 \mathrm{~h}$ in standard conditions, and then washed and stained with calcein-AM. An Olympus Inverted Microscope (model IX71) coupled to a Cell ${ }^{\wedge} \mathrm{R}$ imaging station under standard culture conditions was used in this assay. Shear stress was fixed at 0.5 dyne $/ \mathrm{cm}^{2}$ and events were recorded every $1 \mathrm{~s}$. After $60 \mathrm{~s}$, the twomagnet system was applied for the next $2 \mathrm{~min}$. Imaris software (Bitplane) was used to analyse displacement along the Y-axes (in the direction of the magnetic field).

\section{Transwell Migration Assay}

MNP-treated and -untreated murine NK cells expanded in vitro in the presence of IL-2 or the human NK-92MI cell line were differentially labeled with PKH26 Red or PKH67 Green fluorescent cell-linker kits (Sigma-Aldrich) and mixed at a 1:1 ratio, after which $5 \times 10^{5}$ cells were seeded in $0.1 \mathrm{ml}$ of the appropriate medium in a transwell insert (Corning, 5$\mu \mathrm{m}$ pore). The chemotactic gradient was created by adding the recombinant murine fractalkine (CX3CL1, aa25-105) $(100 \mathrm{ng} / \mathrm{ml}$, R\&D Systems) for murine NK cells or the recombinant human CXCL12 (100 ng/ml, Peprotech) for human NK-92MI to the lower chamber. The cells migrated for $16 \mathrm{~h}$, after which cells from lower chambers were counted by flow cytometry. Cell migration was quantified and normalized for loading into an input well. In some cases, the magnet B was placed below the well.

\section{Statistical Analyses}

The graphs and statistical analyses were made with Prism 5.0 (GraphPad) software. All analyses were performed using one-way ANOVA and Tukey's multiple comparisons post-hoc test. ${ }^{*} p<$ $0.05,{ }^{* *} p<0.01,{ }^{* * *} p<0.001,{ }^{* * * *} p<0.0001$.

\section{RESULTS}

\section{Preliminary Assessment of MNP Interaction With the Human NK-92MI Cell Line}

Several coated MNPs were synthesized and characterized to determine, in an initial study, which was the best to use in this approach. These MNPs had an iron-oxide core of $12.5 \mathrm{~nm}$ and had different surface charges dependending on their coating. By doing this, we obtained positively charged (APS-MNPs), negatively charged (DMSA-MNPs), and noncharged MNPs (DEXT-MNPs). Their complete physico-chemical characterization has been previously described [Table S1; (43)].

When screening the MNPs to determine which was the most appropriate for this cell type, we first analyzed the interaction 
between the human NK cell line, NK-92MI, and the different MNPs, as well as the toxicity they could cause to this cell line.

To study MNP toxicity, we analyzed cell survival after MNP incubation using two different assays. In general, MNP treatment did not affect NK-92MI cell viability, although a certain decrease in the viability of these cells was found after they were treated with high doses of DMSA-MNPs (Figure 1A). Furthermore, analysis of apoptosis/necrosis by flow cytometry showed no significant changes when the cells were incubated with the different MNPs (Figure 1B). We also demonstrated that APSMNP treatment at high dose $(150 \mu \mathrm{g} / \mathrm{mL})$ did not affect NK92MI proliferation at 48 or $96 \mathrm{~h}$ (Figure S1).

Secondly, the amount of MNPs associated with this immunecell type was further assessed. ICP-OES measurements revealed that APS-MNPs led to higher iron detection (14.0 $\pm 4.8 \mathrm{pg} \mathrm{Fe} /$ cell in APS-MNP-treated NK cells vs. $1.7 \pm 0.4 \mathrm{pg}$ Fe/cell and $3.5 \pm$ $0.9 \mathrm{pg} \mathrm{Fe} / \mathrm{cell}$ when treated with DMSA-MNPs and DEXT-MNPs, respectively) (Figure 1C). Taking these results into account, we selected the MNPs coated with APS (APS-MNPs) to continue with the study. We also evaluated the release of APS-MNP by ICP-OES measurements in the culture supernatant of NK-92MI cells after 24, 48, and $72 \mathrm{~h}$. The amount of iron found in the medium at the different timepoints $(12.5 \pm 3.8 \mu \mathrm{g} \mathrm{Fe} / \mathrm{ml}$ at $24 \mathrm{~h}$, $14.0 \pm 6.7 \mu \mathrm{g} \mathrm{Fe} / \mathrm{ml}$ at $48 \mathrm{~h}$ and $8.1 \pm 1.5 \mu \mathrm{g} \mathrm{Fe} / \mathrm{ml}$ at $72 \mathrm{~h})$ were low compared to the amount used to treat the cells $(150 \mu \mathrm{g}$ $\mathrm{Fe} / \mathrm{ml}$ ), indicating that only a small fraction of the iron is being slowly released from the surface of MNP-treated cells.

Furthermore, the subcellular location of these APS-MNPs was determined by means of different microscopy approaches. Confocal microscopy showed that these APS-MNPs remained associated with the plasma membrane (Figure 1D), and a more detailed study through TEM revealed close interaction between the cell membrane and the MNPs (Figure 1E).

\section{Evaluation of the Functionality of the Human NK-92MI Cell Line After MNP Treatment and Magnetic Retention of These Cells in vitro}

NK cells are characterized by the presence of inhibitory and activating receptors on their cell surface, which are essential to carry out their main function $(55,56)$. In addition, other

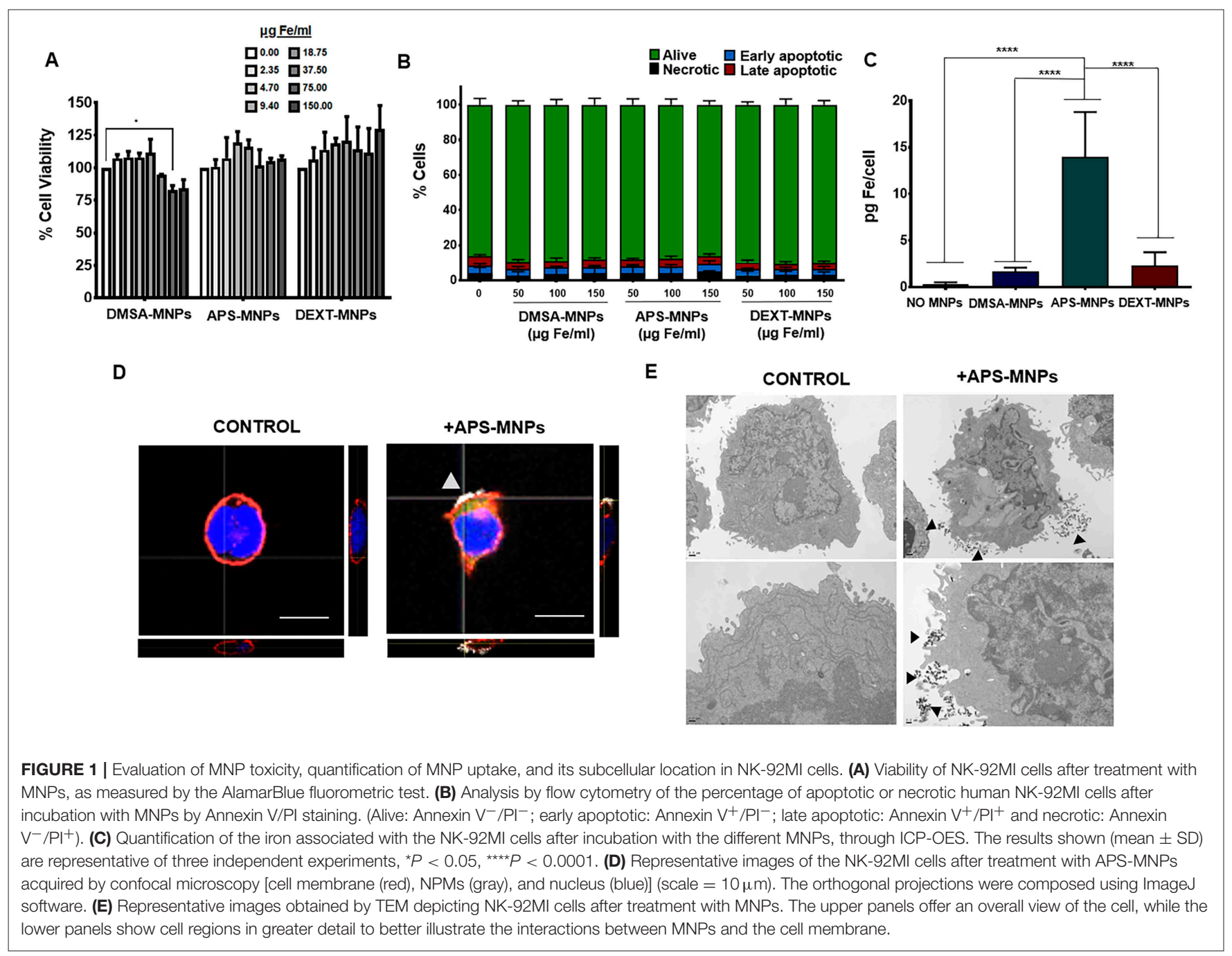


cell-surface molecules such as the activation markers CD69 and CD25, as well as adhesion molecules such as CD54 (ICAM-1), CD11a, or CD62L also play an important role in the activity of these cells. For all these reasons, the expression of these receptors and molecules is important to the functionality of NK cells, making it necessary to analyse their expression after MNP treatment. To do this, the expression of some of these relevant surface molecules was analyzed by flow cytometry after incubation with various concentrations of the selected MNPs (APS-MNPs). As seen in Figure 2A, no significant differences were observed in the expression of the different surface molecules analyzed in the NK-92MI cells (CD56, NKG2D, CD11a, CD95, CD25, CD69, CD45, DNAM-1, or CD2) with the exception of a slight decrease in the expression of the adhesion molecule CD54 at high doses of MNPs (4,246 \pm 120 of MFI in the absence of APSMNPs vs. 3,812 \pm 961 of MFI in the presence of $150 \mu \mathrm{g} \mathrm{Fe} / \mathrm{ml}$ of APS-MNPs) as well as an increase in CD45, which is related to the maturation of lymphoid cells $(6,687 \pm 136$ of MFI in the absence of MNPs vs. 7,232 $\pm 142,7,531 \pm 166$ and 7,163 \pm 214 of MFI in the presence of increasing concentrations of MNPs) [Figure 2A; (57)]. A slight increase, although not statistically significant, in NKp46 expression was also detected in APS-MNP loaded NK-92MI cells. As iron presence can alter MHC class I (58) and transferrin receptor (CD71) expression, we also assessed the expression of these markers in NK-92MI cells (Figure 2A). APS-MNP loading did not alter the expression of HLA-A,B,C, or CD71 in these cells. NK-92MI cells were negative for CD11b, CD27, and KLRG-1 expression and APS-MNP exposure did not induce the expression of these markers (Figure S2). It thus appear that APS-MNP treatment has minimal effects on NK92MI surface markers.

Furthermore, as mentioned above, the membrane protein associated with lysosome CD107a is increased on the surface of NK cells after degranulation and activation by certain stimuli with a capability of inducing a cytolytic response. The expression of CD107a correlates with lysis mediated by NK cells, so it is used

A
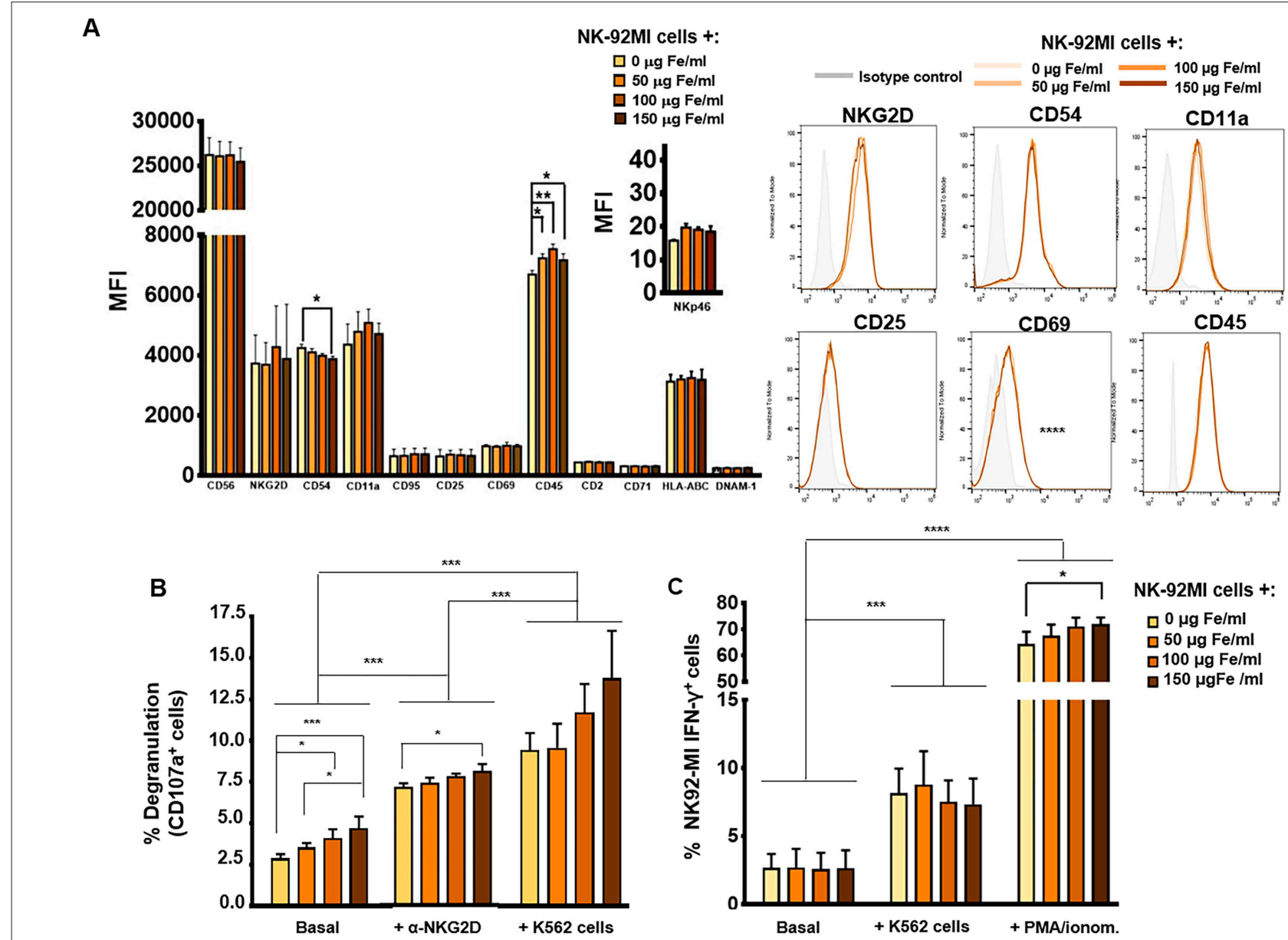

FIGURE 2 | Phenotypic and functional analysis of NK-92Ml cells after their association with MNPs. (A) Quantification (MFI, mean fluorescence intensity) of the expression of relevant cell-surface markers in NK-92Ml cells, after incubation with MNPs and representative histograms. (B) Degranulation capacity of NK-92Ml cells, after being treated with different concentrations of MNPs and after exposure to a range of stimuli. (C) Quantification of the percentage of IFN- ${ }^{+}$NK-92MI cells after MNP treatment and exposure to a number of stimuli. The data (mean $\pm \mathrm{SD}$ ) are representative of three independent experiments, ${ }^{\star} P<0.05$, ${ }^{\star \star} P<0.01$, ${ }^{\star \star \star} P<0.001,{ }^{\star \star \star \star} P<0.0001$. 
as a marker to determine whether these cells develop defects in their cytolytic function (59). After stimulation of NK cells with the K562 target cell line, or through cross-linking with a ligand for NK cell-activating receptor such as $\alpha$-human NKG2D, we did not observe, in general, significant differences in CD107a expression when using increasing concentrations of APS-MNPs, even though basal or non-specific degranulation was increased $(2.9 \pm 0.3 \%$ in the absence of MNPs vs. $3.6 \pm 0.3 \%, 4.1 \pm 0.5 \%$, and $4.7 \pm 0.7 \%$ in the presence of increasing concentrations of MNPs) (Figure 2B). The results also showed a slight increase in the degranulation obtained after stimulation with the $\alpha$-human NKG2D when treated with $150 \mu \mathrm{g} \mathrm{Fe} / \mathrm{ml}$ of APS-MNPs $(7.2 \pm$ $0.2 \%$ in the absence of MNPs vs. $8.1 \pm 0.3 \%$ with $150 \mu \mathrm{g} \mathrm{Fe} / \mathrm{ml}$ of APS-MNPs) (Figure 2B).

Another important aspect in the functionality of NK cells is the rapid production of various pro-inflammatory cytokines, one of the most important of which is IFN- $\gamma$ (8). Therefore, their capacity to produce IFN- $\gamma$ after being co-cultured with the K562 target cell line or in the presence of PMA/ionomycin was further assessed by flow cytometry. The results showed that this capacity remains intact after MNP treatment. However, the percentage of NK-92MI IFN- $\gamma^{+}$cells was slightly increased after treatment at high doses of MNPs and when exposed to PMA/ionomycin [64.5 $\pm 4.6 \%$ in the absence of MNPs and $72.1 \pm 2.4 \%$ at the highest dose of MNPs (150 $\mu \mathrm{g} \mathrm{Fe} / \mathrm{ml})$ ] (Figure 2C).
In addition, we proceeded to determine whether the NK92MI cells evidenced defects in their conjugation capacities with different target cells following MNP treatment. Conjugation with target cells is of great relevance, as physical interaction among these cells is a key step with which NK cells exert their cytolytic activity (60). No significant differences were detected in the conjugation kinetics obtained between the human NK cells left free of APS-MNPs or associated with different concentrations of APS-MNPs and the K562 human cell line (Figure 3A). Further, no differences or defects in the conjugation of these cells were found, even in the presence of APS-MNPs, both after short times (2-5 $\mathrm{min})$, when they always remained around $2-4 \%$, and at longer times ( $45 \mathrm{~min}$ ), around $30-40 \%$ in both cases.

Furthermore, we evaluated whether the association between the NK-92MI cells and APS-MNPs affected their direct cytolytic capacity against target cells. To do this, the percentage of lysed target cells at different effector-target cell ratios was analyzed. No significant differences were observed in the different, increasing concentrations of APS-MNPs assessed $(9.3 \pm 5.5 \%$ lysis in the absence of MNPs vs. $7.1 \pm 3.7 \%$ lysis in the presence of $150 \mu \mathrm{g}$ $\mathrm{Fe} / \mathrm{ml}$ of APS-MNPs at lower ratios in co-culture with K562 cells and $21.8 \pm 7.4 \%$ lysis vs. $22.0 \pm 8.2 \%$ lysis, respectively, at higher ratios) (Figure 3B).

After analyzing the activation and cytolytic activity of APS-MNP-loaded NK-92MI cells, we proceeded to evaluate

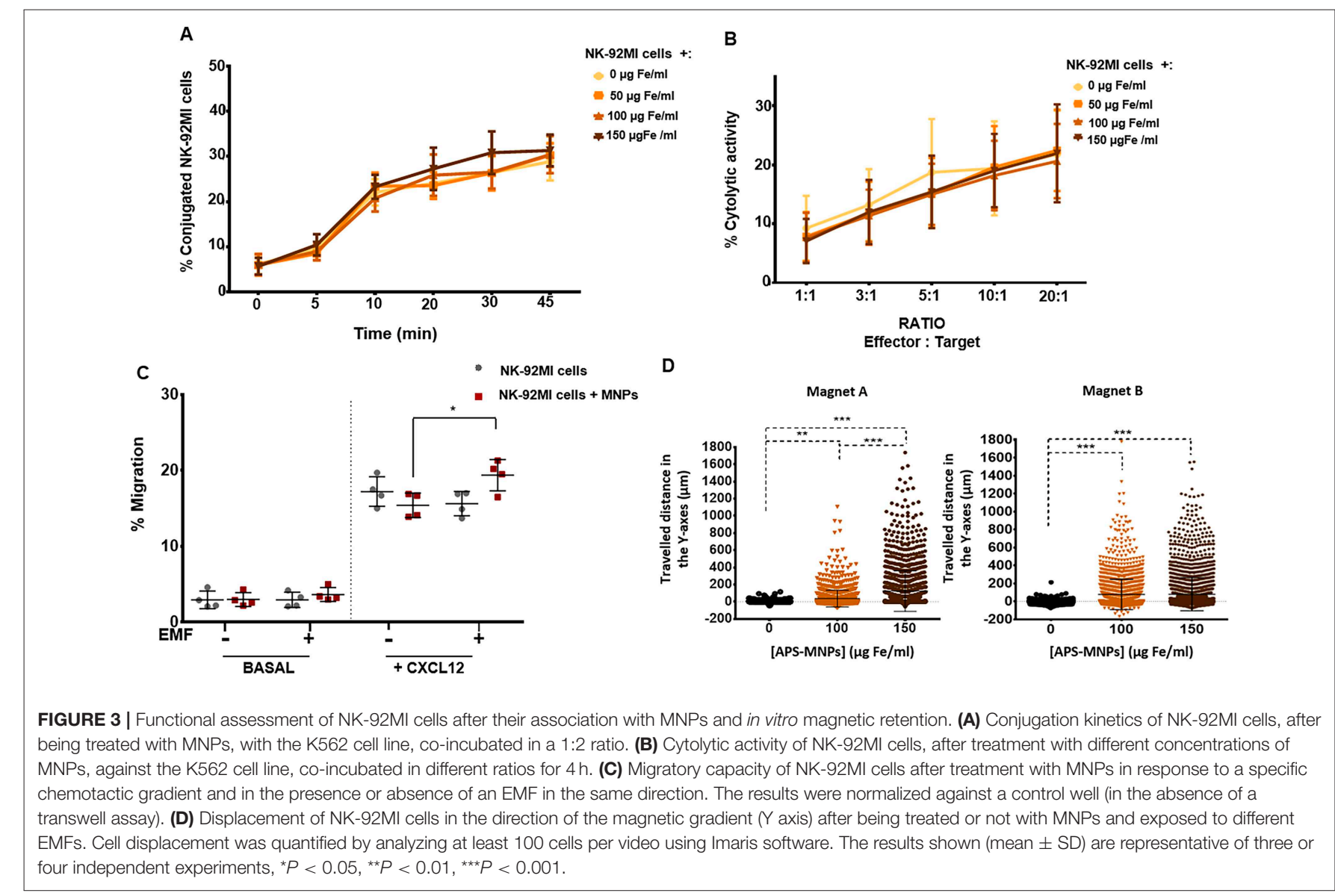


the capacity of these cells to respond to a biological factor such as a chemotactic gradient. NK cells respond to various chemokines, which directly affects their location both during their development and maturation and during an immune response (61). Transwell assays showed that the presence of APSMNPs in the NK-92MI cells affected the cell migration in a mild but non-significant way in response to a chemotactic gradient $(17.2 \pm 1.9 \%$ migration in the absence of APS-MNPs vs. $15.4 \pm$ $1.6 \%$ migration in the presence of APS-MNPs) (Figure 3C). In addition, the application of an EMF in the same direction as in the chemotactic gradient produced an increase in the migration of the cells associated with the MNPs (15.4 \pm 1.6 vs. $19.4 \pm$ $2.1 \%$ migration in the presence of MNPs and in absence or the presence of an EMF, respectively) (Figure 3C).

As NK cells are continuously circulating between the blood and different tissues, we proceeded to study whether it was possible to magnetically retain these APS-MNP-loaded NK92MI cells in a dynamic flow system. We assessed different concentrations of MNPs as well as different magnetic forces, measuring the displacement of these cells toward the magnetic gradient to which they were exposed. This retention increased with greater numbers of APS-MNPs associated with the cells (56 \pm 97 vs. $124 \pm 236 \mu \mathrm{m}$ when treated with 100 and $150 \mu \mathrm{g} \mathrm{Fe} / \mathrm{ml}$, respectively, and using the magnet $\mathrm{A}$ ) and with higher strength of the magnetic gradient (Figure 3D).

\section{Application to a Primary NK Cell Model: Murine NK Cells Expanded in vitro in the Presence of IL-2}

Once the interaction between the MNPs and the human NK92MI cell line had been carefully evaluated, we moved to primary murine NK cells, which were isolated from the spleen of mice and expanded in vitro in the presence of IL-2 for 7 days. The purity of these primary cultures was always checked at day 0 , after isolation, and at day 7, after expansion with IL-2 (Figure S3).

First, we confirmed that the different MNPs used in this study did not cause significant toxicity over these primary NK cells (Figures 4A,B) by applying the same methods used previously to assess viability of the human NK cell line. However, a slight decrease in cell viability in the presence of certain concentrations of APS-MNPs was observed (Figure 4A). Similarly, the analysis of apoptosis/necrosis by flow cytometry showed no significant changes when the cells were incubated with the different MNPs, but a slight increase in early apoptosis was seen in the presence of DMSA-MNPs or APS-MNPs $(8.8 \pm 2.1 \%$ in the absence of MNPs vs. $16.5 \pm 2.8$ and $14.5 \pm 2.6 \%$ after the highest doses of DMSAand APS-MNPs) (Figure 4B).

We also verified that the APS-MNPs were the MNPs that associated the most with these cells, around 14-15 pg Fe per cell (Figure 4C). This value was very similar to the one previously

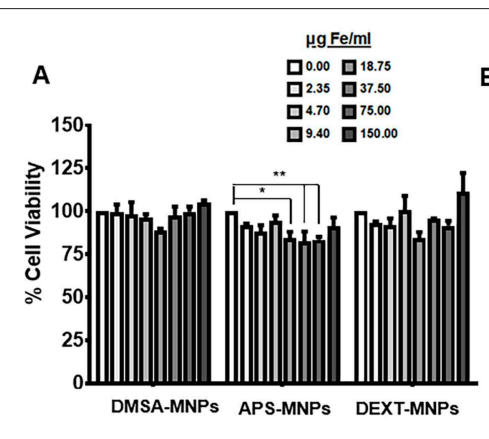

D

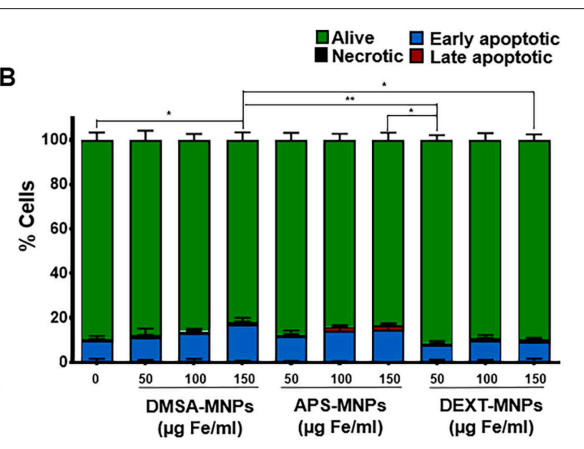

E

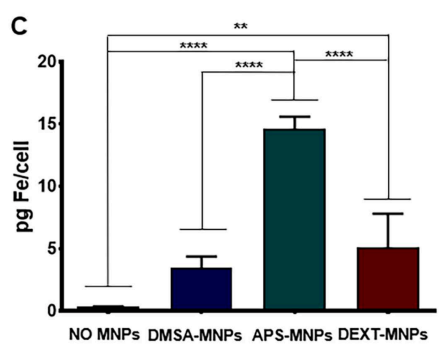

CONTROL
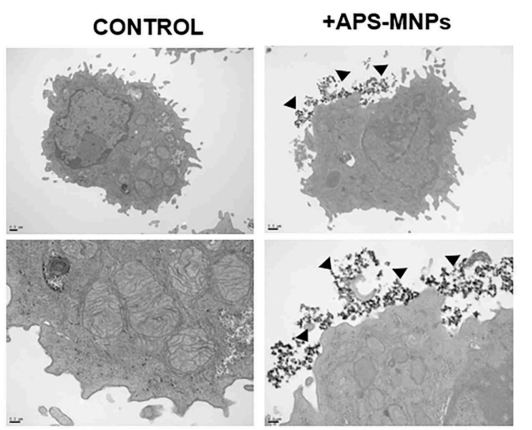

FIGURE 4 | Evaluation of MNP toxicity, quantification of MNP uptake and determination of subcellular location in murine NK cells. (A) Cell viability of murine NK cells after treatment with MNPs, measured by the AlamarBlue fluorometric test. (B) Analysis by flow cytometry of the percentage of apoptotic or necrotic murine NK cells after incubation with MNPs by Annexin V/PI staining. (Alive: Annexin $\mathrm{V}^{-} / \mathrm{PI}^{-}$; early apoptotic: Annexin $\mathrm{V}^{+} / \mathrm{PI}^{-}$; late apoptotic: Annexin $\mathrm{V}^{+} / \mathrm{PI}^{+}$and necrotic: Annexin $\mathrm{V}^{-} / \mathrm{PI}^{+}$). (C) Quantification of the iron associated with the murine NK cells after incubation with the different MNPs, through ICP-OES. The results shown (mean \pm SD) are representative of three independent experiments, ${ }^{\star} P<0.05,{ }^{\star \star} P<0.01,{ }^{\star \star \star} P<0.001,{ }^{\star \star \star \star} P<0.0001$. (D) Representative images of the murine NK cells after treatment with APS-MNPs acquired by confocal microscopy [cell membrane (red), NPMs (gray), and nucleus (blue)] (scale = 10 $\mu \mathrm{m}$ ). The orthogonal projections were composed using ImageJ software. (E) Representative images obtained by TEM of murine NK cells after treatment with MNPs. The upper panels offer an overall view of the cell, while the lower panels depict cellular regions in greater detail to better illustrate the interactions between MNPs and the cell membrane. 
found in the human NK cell line. In addition, we visualized the association between APS-MNPs and the primary murine NK cells by confocal microscopy and TEM. Both imaging techniques illustrated the interaction between the APS-MNPs and the cell surface of these murine NK cells, as in the human NK-92MI cell line (Figures 4D,E).

We then continued by assessing the effect APS-MNPs could have on the phenotype and the expression of several surface molecules of these primary murine NK cells by flow cytometry. No significant differences were observed in the expression of most of the different markers analyzed in IL-2 expanded murine NK cells after MNP treatment (NK1.1, NKG2D, CD62L, CD27, CD11b, Ly49A+D, Ly49D, Ly49F, or NKp46), though a slight decrease in the CD69 activation marker was observed after treatment with high concentrations of APS-MNPs $(4,974 \pm 518$ vs. $4,051 \pm 713$ of MFI) (Figure 5A). Therefore, APS-MNPs did not significantly influence the murine NK phenotype.

The degranulation capacity of these primary murine NK cells as well as their ability to produce IFN- $\gamma$ when associated with APS-MNPs was further evaluated. After stimulation through cross-linking with NK cell activating receptor ligands (such as NKG2D, NK1.1, and NKp46) $(62,63)$, we determined the presence of the degranulation marker in these NK cells when associated with increasing concentrations of APS-MNPs. No significant differences were observed in the degranulation of these cells in the presence of the MNPs after the different stimuli, even though basal or non-specific degranulation was significantly increased $(12.0 \pm 2.5 \%$ in the absence of MNPs vs. $19.3 \pm 4.1$ and $23.5 \pm 7.0 \%$ in the presence of the highest concentrations of APS-MNPs) (Figure 5B).

In addition, we analyzed the production of IFN- $\gamma$ by murine NK cells expanded in the presence of IL-2 in the presence of different concentrations of APS-MNPs and after exposure to various stimuli. This factor was analyzed after activation of the murine NK cells by cross-linking with ligands of different activating receptors (NKG2D, NK1.1, and NKp46) by means of an ELISA assay $(62,63)$. No significant differences were observed in the production of IFN- $\gamma$ after incubation with the APS-MNPs (Figure 5C).

We then assessed in detail the conjugation capacity and cytotoxicity when treated with increasing concentrations of APSMNPs and co-cultured with the YAC-1 and RMA-S murine cell

A

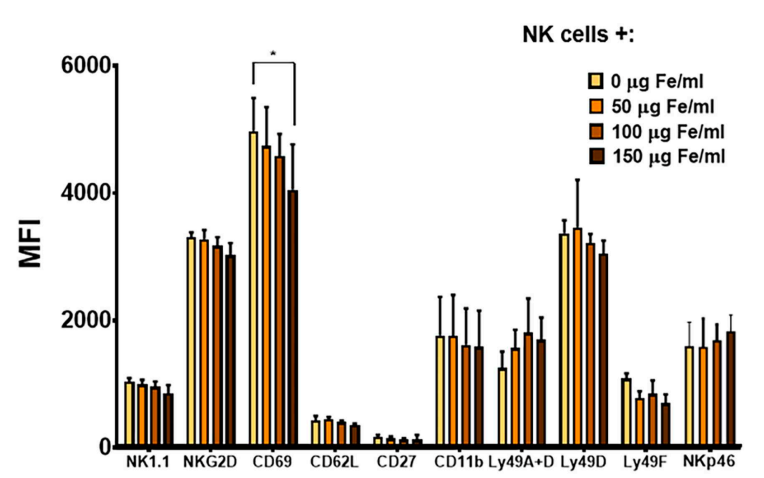

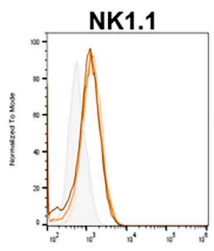

CD11b
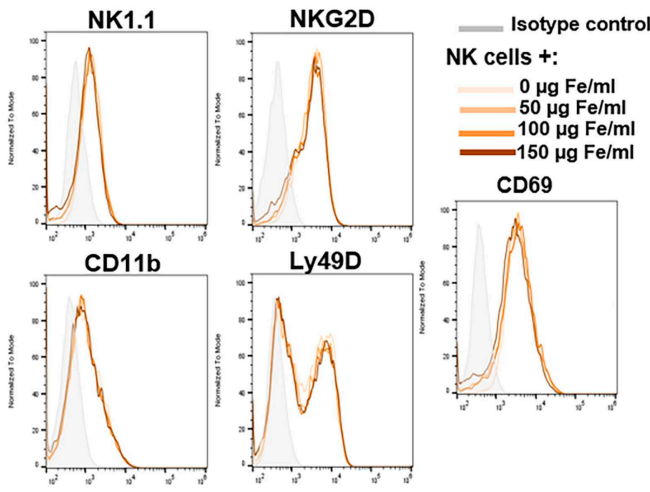

CD69
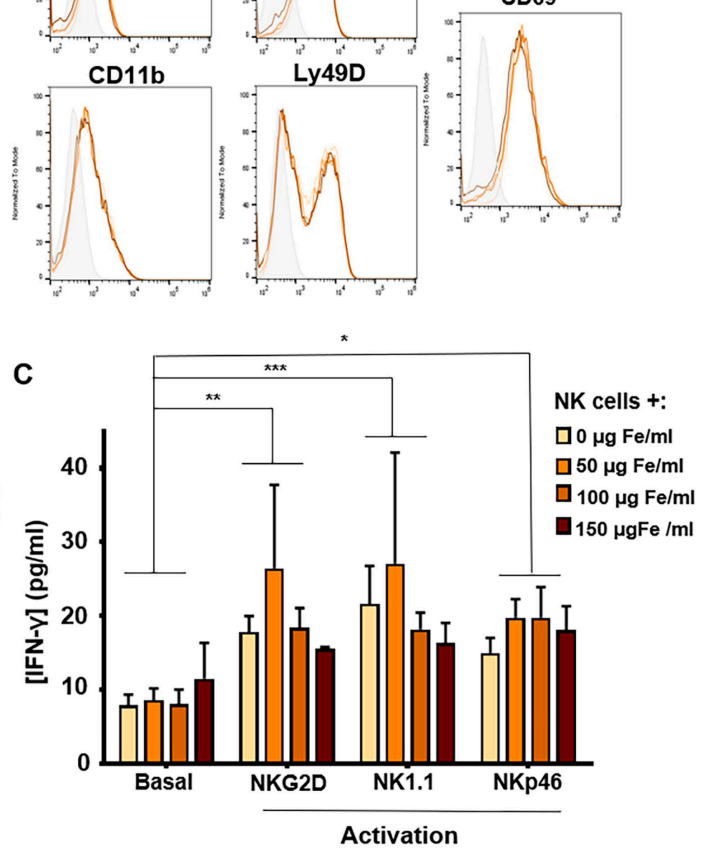

FIGURE 5 | Phenotypic and functional analysis of murine NK cells after their association with MNPs. (A) Quantification (MFI, mean fluorescence intensity) of the expression of relevant cell-surface markers in murine NK cells after incubation with MNPs and representative histograms. (B) Degranulation capacity of murine NK cells after treatment with different concentrations of MNPs and after exposure to a variety of stimuli. (C) Quantification of IFN- $\gamma$ production by murine NK cells after MNP treatment and exposure to a range of stimuli, measured by ELISA assay. The data (mean \pm SD) are representative of three independent experiments, ${ }^{\star} P<0.05$, ${ }^{\star \star} P<0.01,{ }^{\star \star *} p<0.001,{ }^{\star * \star \star} P<0.0001$. 
lines, which are susceptible to being lysed by the murine NK cells. No significant differences in conjugation were detected between the primary murine NK cells that remained free from APS-MNPs and when these cells were associated with different concentrations of APS-MNPs (Figure 6A), and no difference was found in their cytolytic activity (Figure 6B).

The process of lymphocyte recruitment, which comprises a complex cascade of different events starting with the adhesion of the cells to the endothelium and through to the transendothelial migration (64), plays an essential role during the immune response. We therefore evaluated whether the presence of APSMNPs on the surface of the murine NK cells affected their adhesion to an endothelium, as well as the ability of these cells to transmigrate. No significant differences were observed in adhesion capacity (Figure 7A) or ability to transmigrate (around 73\% transmigration at all times) (Figure 7A). However, a slight increase in adhesion capacity was observed in the presence of APS-MNPs ( $16 \pm 4$ cells adhered/field in the absence of MNPs vs. $20 \pm 7$ cells adhered/field in the presence of the lowest dose of MNPs) (Figure 7A), possibly due to the presence of the MNPs on the surface, which could interact with the endothelial cells.

Further analyses of the chemotactic response of the primary murine NK cells in the presence of APS-MNPs revealed that the presence of MNPs on the cell surface did not significantly affect the migration of these cells in response to a chemotactic gradient. However, the application of an EMF in the same direction as the chemotactic gradient produced a slight but not significant increase in the migration of the primary murine $\mathrm{NK}$ cells associated with the MNPs (50.4 \pm 10.5 vs. $61.1 \pm 12.7 \%$ migration in the presence of APS-MNPs and in the absence and presence of an EMF, respectively) (Figure 7B).

Similarly to NK-92MI cells (Figure 4D), the magnetic retention of APS-MNP-loaded primary murine NK cells in the presence of flow forces (Figure 7C) increased with greater APS-MNP concentrations as well as with the strength of the magnetic force.

\section{DISCUSSION}

NK cells are known to play an essential role in host immunity to cancer and are ideal candidates for use in the fight against this complex disease. Furthermore, NK cell-transfer therapy has proven to be an effective means of treating some adult hematological malignancies, thus reinforcing the idea that $\mathrm{NK}$ cells can be an important therapeutic tool for the treatment of other types of cancer. In fact, some therapies based on this concept are already being tested at the clinical level, although some with moderate results (32). As with other cell-based therapies, NK cell-transfer therapy has limitations, such as the dispersion of in vivo-administered NK cells, and strategies designed to solve this problem are being studied widely. One promising approach combines MNPs and EMFs to localize specific cell types in a region of interest. This approach has proven efficient when different types of cells are used in targeting, including NK cells. For example, previous studies showed how lymphoid cells such as T cells, when associated with MNPs, can be magnetically retained in the lymph nodes, which could be useful in modulating the immune response in the context of

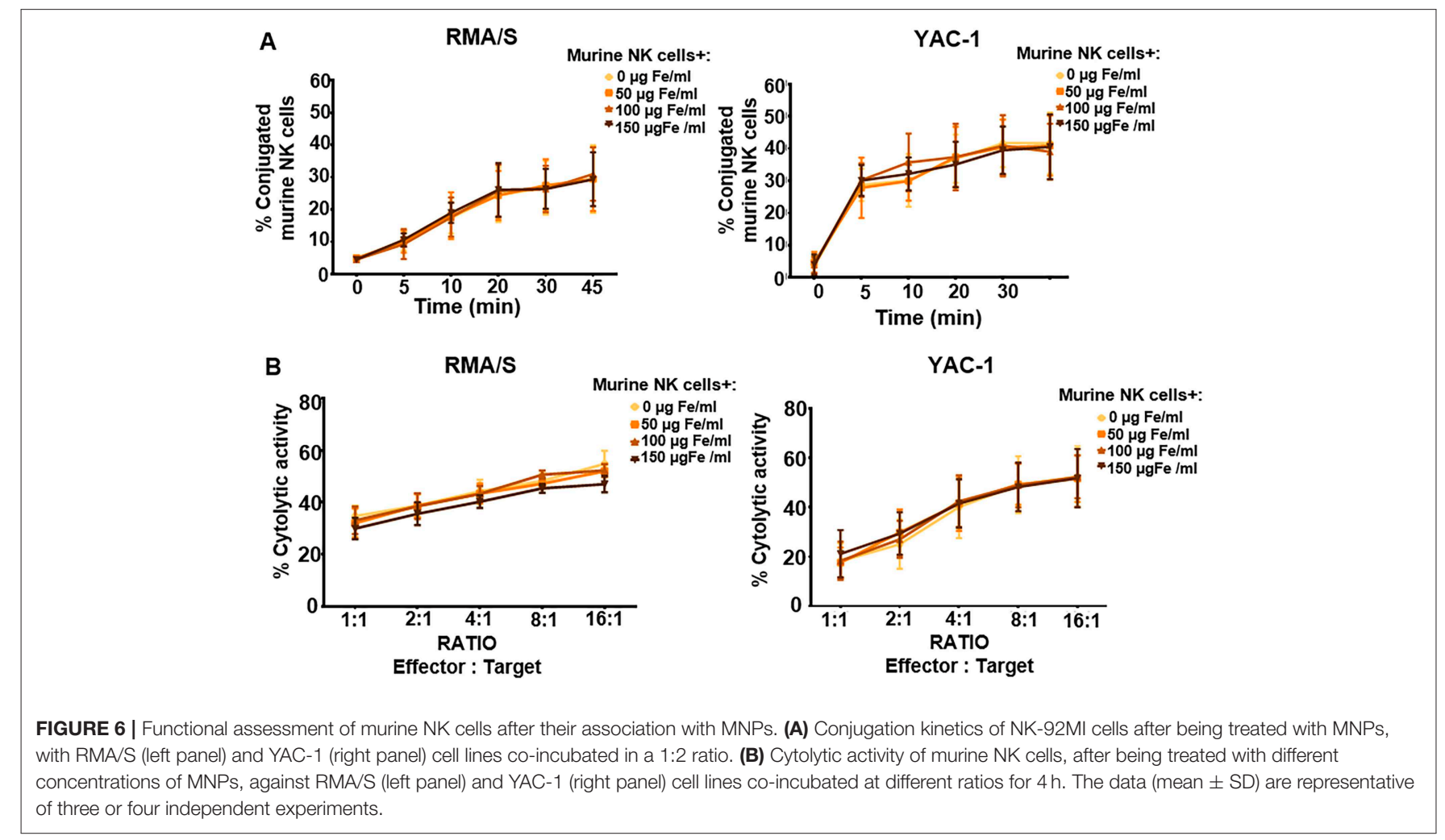




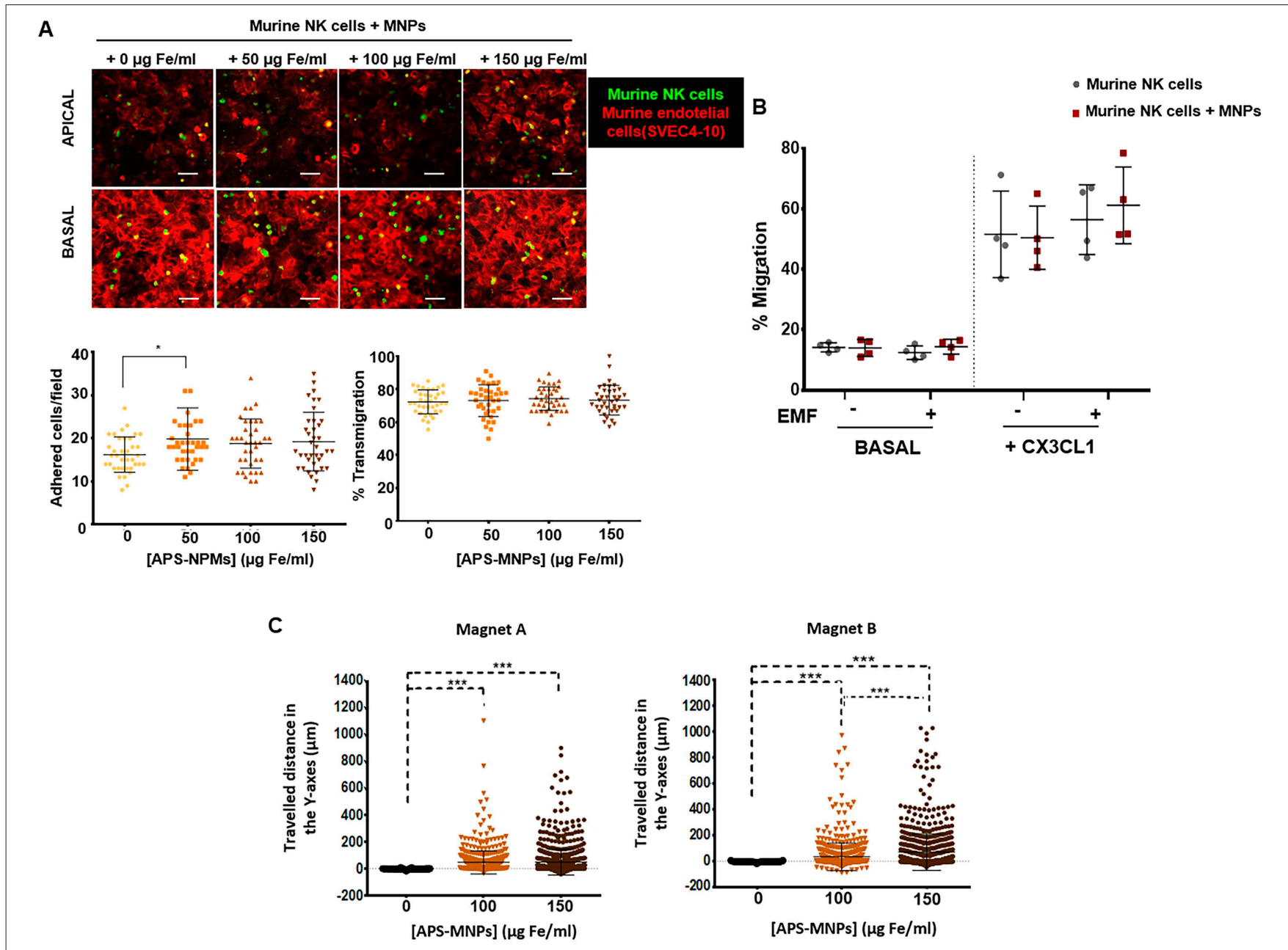

FIGURE 7 | Transmigration and in vitro retention of MNP-loaded murine NK cells through the application of an EMF in flow chambers and analysis of their chemotactic response. (A) Representative images of murine NK cells, treated with NPMs or not, migrating over a monolayer of murine endothelial cells (SVEC-4 cell line), acquired through confocal microscopy. The upper panel represents the apical part of the monolayer, while the lower panel represents the basal part [murine NK cells (green), cytoskeleton (red)]. Scale: $100 \mu \mathrm{m}$. Quantification of the adhesion (left panel) and transmigration (right panel) exhibited by murine NK cells in the presence of increasing concentrations of MNPs through murine endothelial cells. The results shown (mean \pm SD) are representative of three independent experiments, analyzing at least 50 fields per condition, ${ }^{\star} P<0.05$, ${ }^{\star \star \star} P<0.001$. (B) Migratory capacity of murine NK cells after treatment with MNPs in response to a specific chemotactic gradient and in the presence or absence of an EMF in the same direction. The results of this test were normalized against a control well (in the absence of transwell assay). (C) Displacement of murine NK cells in the direction of the magnetic gradient (Y axis) after being treated with MNPs or not and exposed to different EMFs. Cell displacement was quantified by analyzing at least 100 cells per video using Imaris software. The results shown (mean \pm SD) are representative of three or four independent experiments, ${ }^{\star} P<0.05,{ }^{\star \star \star} P<0.001$.

disease (43). This strategy can also be applied to other regions of interest, such as a tumor, increasing the antitumor immune response carried out by activated effector cells. To date, some studies have used this type of strategy to accumulate stem cells, mesenchymal cells, macrophages, or dendritic cells as part of tissue-regeneration therapies or in therapy for autoimmune disorders $(29,36-40)$. However, use of MNPs and EMFs to redirect lymphoid cells such as T or NK cells for the treatment of cancer is limited and has been scarcely investigated $(29,30)$. One of these studies (30), showed that NK92MI cells loaded with MNP by magnetic transfection can be targeted to the tumor site by an EMF, but the in vitro functional analysis of MNP-loaded NK92MI cells was limited to a cytotoxicity assay. As such, a more extensive evaluation of the effects that MNP loading could have on NK cell function as well as optimization of magnetic retention are required for these approaches to reach the clinic. In addition, primary $\mathrm{NK}$ cells are known to be highly resistant to transfection methods $(41,42)$, likely decreasing the efficacy of these approaches.

We have previously shown that APS-MNPs attached to the surface of primary murine $\mathrm{T}$ cells can be specifically targeted to lymph nodes by using an EMF (43). This prompted us in this study to examine the influence of MNPs on the functionality of NK cells so as to determine the extent to which specific magnetic retention of fully functional NK cells could be promoted. To this end, we first assessed a model with great clinical significance: 
NK-92MI, a human NK cell line that derives from the clinically approved NK-92 cell line $(26,48,49)$ subsequently moving on to a model of primary murine NK cells.

It is commonly described that MNPs seldom cause significant toxicity in different immune-cell types, with over $80 \%$ cell viability associated with this treatment approach (65). There are studies, however, that evidence the toxicity of some MNPs in lymphoid cells, primarily when high doses, certain coatings, and long exposure times are used (66-68). The MNPs employed here did not have a substantial toxic effect on the different models of NK cells, and as described previously, cell viability remained over $75-80 \%$ at all times. Primary murine NK cells displayed a slightly greater decrease in cell viability in some incubation conditions, probably due to higher susceptibility to apoptosis and senescence after a 7-days cytokine expansion.

The presence of the MNPs on the surface of the murine and human NK cells as observed by different types of microscopy correlated with previous studies using these MNPs and other types of lymphoid cells such as murine and human T cells (43). In this earlier study, the close association between the MNPs and the membrane of $\mathrm{T}$ cells did not significantly alter the main functional aspects of these cells, and this feature must be further evaluated in these NK cell models.

To date, only a few detailed studies have described the effect of MNPs on the functionality of cytotoxic lymphoid cells such as $\mathrm{T}$ and NK cells. Most analyse certain functional aspects of these cells after their association with MNPs in order to track these aspects by means of magnetic resonance imaging. Concerning $\mathrm{T}$ cells, some reports show that the proliferation of these cells in response to specific antigens, as well as their cytotoxic capacity against certain cell targets or the production of certain cytokines, do not seem to be affected by MNPs in vitro (69-72). There are also studies that show how effector $\mathrm{T}$ cells maintain their cytotoxic and antitumor activity in vivo, and these cells are able to migrate to and infiltrate the tumor with no apparent difficulty $(73,74)$. However, certain defects in the cytolytic capacity and cytokine production of these cells have been described, but only in the presence of very high doses of MNPs (>500 $\mu \mathrm{g} \mathrm{Fe} / \mathrm{ml}$ ) (67). Taken together, the studies described above seem to indicate that MNPs could be associated with effector $\mathrm{T}$ cells, possibly causing them to preserve their main functions.

Regarding NK cells, a small number of studies have evaluated the influence that MNPs can have on human NK cell lines such as NK-92 or KHYG-1, but none have explored this influence on primary human or murine NK cells. Existing studies show that NK cell lines preserve their cytolytic capacity in vitro and are able to migrate and infiltrate the tumor in vivo in much same way as when these cells are not associated with MNPs (30, 7579). Therefore, these studies also seem to indicate that NK cells could associate with MNPs without impairment to their main functions. However, a more exhaustive analysis of these and other functional aspects of these cells, as well as of primary NK cells, is essential, and should test the degree to which these functions remain intact after association with MNPs, and in particular, with the particular MNPs used in this work (APS-MNPs).

In this study, we first analyzed the phenotype, showing that the association of the NK cells with APS-MNPs did not produce significant differences in the levels of expression of important surface markers such as adhesion molecules, integrins, as well as other types of activating or inhibitor receptors. This finding is in agreement with previous studies that show that MNPs may not significantly affect expression levels of surface markers in a wide variety of immune cells $(38,39,72,80-82)$.

Another aspect that has been assessed in this work is the degranulation capacity of NK cells after MNP treatment. As mentioned previously, the presence of the functional marker CD107a increases in the cytolytic cells once they have been activated and have released their granules, which contain the enzymes that will lyse the target cells. Therefore, it is an indirect measure of cytolytic capacity (59) and can be produced either by activation in the presence of target cells or through crosslinking with ligands of activating receptors $(62,63)$. Our analysis of degranulation capacity in NK cells, both in the primary murine NK cells and in the NK-92MI cell line, showed a dose-dependent increase in spontaneous degranulation, that is, in the absence of stimuli, while degranulation in the presence of different stimuli probably increased only because of the increase in basal levels. This could be due to some non-specific activation of the NK cells by the APS-MNPs.

One of the key steps required for an effector NK cell to exert its cytolytic activity against malignant cells is the physical interaction between both cell types (60), a phenomenon known as conjugation. The dynamics of conjugate formation between primary murine NK cells or NK-92MI cells with their corresponding target cells did not appear to be affected by the presence of the APS-MNPs in the NK cell membrane. These results verify, therefore, that the presence of APS-MNPs on the cell surface of cytotoxic cells does not affect their ability to physically interact with and adhere to cells susceptible to being lysed so that NK cells can recognize them and be subsequently activated.

As we have seen, the MNPs do not seem to negatively affect the conjugation and degranulation capacities of the NK and $\mathrm{T}$ cells, and thus their direct cytotoxic capacity was subsequently evaluated against several targets. The cytotoxicity of NK cells, when induced by such cell targets that present null or very low levels of MHC-I as RMA/S (against primary murine NK cells) or K562 (against the NK-92MI cell line) or the activating receptor NG2D ligand, YAC-1 (against primary murine NK cells), was not affected by the presence of MNPs. Both murine and human NK cells are capable of being activated and producing lysis of target cells in vitro, even in association with MNPs, as previously described (30, 72-74, 76-79).

In addition, the ability to produce IFN- $\gamma$ after the introduction of various stimuli was also evaluated, as this is one of the most important pro-inflammatory cytokines that produce this type of cells (8). Both murine and human NK cells were able to produce IFN- $\gamma$ after activation by a variety of non-specific stimuli such as PMA and ionomycin, as well as specific stimuli such as target cells (K562 cells) or the cross-linking of activating receptors (NK1.1, NKG2D, and NKp46) (62,63), doing so at similar levels in the presence or absence of increasing concentration of MNPs. These findings are similar to previously obtained 
results $(67,70,71)$. However, an increase was observed in the percentage of NK-92MI cells able to produce IFN- $\gamma$ after nonspecific stimulation with PMA and ionomycin when the highest dose of MNPs was used, although a more exhaustive analysis would be necessary to understand the cause of this increase. It is important to note that NKG2D activation is able to stimulate IFN- $\gamma$ production in murine but not in human NK cells $(83,84)$, and as a result the specific production of IFN- $\gamma$ in NK-92MI cells was only analyzed by measuring activation in the presence of target cells (K562 cells).

It is also relevant that these cells with antitumor activity are continuously circulating and recruited from the bloodstream to the tumor through different processes $(85,86)$. Therefore, we also evaluated the capacity of primary murine NK cells to adhere to an endothelium as well as their transmigration capacity through an endothelium monolayer, finding no defects in this capacity. We observed that the presence of MNPs in the membrane of the cells could occasionally increase their adhesion to endothelial cells. Hypothetically, this may be because these MNPs exposed in the membrane interacted with the endothelial cells. The results obtained in this research are consistent with several studies that showed that NK cells associated with MNPs could migrate and infiltrate the tumor in vivo without difficulty (72-74, 76-79).

Chemotactic gradients are also essential to recruit NK cells to the different regions where they are required. When associated with MNPs, the two models used in this study showed no significant alteration in their chemotactic response. However, the application of an EMF slightly increased the migration of these APS-MNP-loaded murine and human NK cells toward their respective chemotactic gradients. This EMF could facilitate the migration of these APS-MNP-loaded cells to the chemotactic gradient, as previously reported (43).

After evaluating different effector functions of the NK cells, and having observed that the MNPs did not cause alterations or defects in these cells, which can maintain their functionality more or less intact in the presence of MNPs, we proceeded to evaluate whether the magnetic retention of these APS-MNPloaded NK cells could be achieved in vitro in the presence of flow forces similar to the ones in the capillaries. This could have potential for subsequent in vivo application. Here, the magnetic retention of both murine and human NK cells associated with increasing doses of APS-MNPs was evaluated in a dynamic flow system using magnets with different magnetic forces. The displacement of APS-MNP-loaded murine or human NK cells toward the EMF obtained was similar to the one observed in a previous study using murine and human $\mathrm{T}$ cells (43). These results confirmed that this magnetic retention increases with the amount of MNPs linked to the cells as well as with increasing levels of magnetic force.

Our findings lend further support for the use of an EMF to promote in vitro retention of lymphoid cells such as NK cells when associated with APS-MNPs and in the presence of flow forces. Previous studies have shown that MNPs or MNPloaded cells can be injected systemically and targeted to a certain region in mice by applying an EMF such as an external magnet (87-90). Nevertheless, this could only be applied to superficial areas as well as in a model with a reduced size such as mice. An alternative approach to address these questions could be magnetic resonance targeting (MRT). Some studies showed that MRI systems could be used to simultaneously improve cell targeting and tracking $(29,91)$ and probably help accumulate cells to specific regions like metastatic lesions. This could be of great relevance for NK cell targeting to metastasis, as high ratio of NK cells to tumor cells can be effective for eradicating these lesions. In this regard, Muthana et al. published a study about the potential of MRI scanners to target one or more tissues (91). In this work, they were able to drive MNP-loaded human macrophages to prostatic tumors in mice. Another work recently showed successful MRI guidance of MNPloaded T cells to tumor sites (29). These results encourage the use of clinical MRI scanners to promote magnetic targeting in deep tissues.

\section{CONCLUSIONS}

Using a range of in vitro studies, this study shows that the attachment of APS-MNPs to the surface of different models of NK cells did not crucially affect the functionality of these cytolytic cells. Furthermore, the magnetic retention of these APS-MNP-loaded murine and human NK cells was successfully achieved, thereby confirming the potential of this approach to promote the specific accumulation of these cytolytic cells in vivo. This combined therapy could ensure that a larger number of totally functional NK cells reaches the tumor, leading to more efficient treatment and better clinical outcomes. This knowledge could be used to design more effective treatment protocols.

\section{DATA AVAILABILITY}

The datasets generated for this study are available on request to the corresponding author.

\section{AUTHOR CONTRIBUTIONS}

DB, JR, and LS-O designed the study and analyzed the data. LS-O and JR conducted the experiments. YP and SP-Y assisted with some experiments and gave technical support. DB, JR, and LS-O prepared and revised the manuscript, the final version of which was read and approved by all.

\section{FUNDING}

This work was supported in part by grants from the Spanish Ministry of Economy, Industry and Competitiveness (SAF-201454057-R and SAF-2017-82223-R to DB). LS-O and YP receive predoctoral FPU grants (FPU13/05037 and FPU15/06170, respectively) from the Spanish Ministry of Economy, Industry and Competitiveness. JR was supported by a JAEdoc grant cofinanced by the CSIC and the European Social Foundation. 


\section{ACKNOWLEDGMENTS}

The authors thank M. P. Morales and her group at the Instituto de Ciencia de Materiales de Madrid (ICMM) for continuous support and assistance with the synthesis and characterization of the magnetic nanoparticles. The authors thank Dr. A. PérezMartínez (IdiPaz) for kindly providing us with the NK-92MI and K562 cell lines and Dr. B. Chambers (Karolinska Institute) for the RMA/S cell line. We would also like to thank the CNB confocal microscopy facility, the CNB flow cytometry facility,

\section{REFERENCES}

1. Kiessling R, Klein E, Pross H, Wigzell H. "Natural" killer cells in the mouse. II. Cytotoxic cells with specificity for mouse Moloney leukemia cells. Characteristics of the killer cell. Eur J Immunol. (1975) 5:117-21. doi: 10.1002/eji.1830050209

2. Kiessling R, Klein E, Wigzell H. "Natural" killer cells in the mouse. I. Cytotoxic cells with specificity for mouse Moloney leukemia cells. Specificity and distribution according to genotype. Eur J Immunol. (1975) 5:112-7. doi: 10.1002/eji.1830050208

3. Herberman RB, Nunn ME, Holden HT, Lavrin DH. Natural cytotoxic reactivity of mouse lymphoid cells against syngeneic and allogeneic tumors. II. Characterization of effector cells. Int J Cancer. (1975) 16:230-9. doi: 10.1002/ijc.2910160205

4. Gregoire C, Chasson L, Luci C, Tomasello E, Geissmann F, Vivier E, et al. The trafficking of natural killer cells. Immunol Rev. (2007) 220:169-82. doi: 10.1111/j.1600-065X.2007.00563.x

5. Sutlu T, Alici E. Natural killer cell-based immunotherapy in cancer: current insights and future prospects. J Intern Med. (2009) 266:154-81. doi: 10.1111/j.1365-2796.2009.02121.x

6. Fauriat C, Long EO, Ljunggren HG, Bryceson YT. Regulation of human NKcell cytokine and chemokine production by target cell recognition. Blood. (2010) 115:2167-76. doi: 10.1182/blood-2009-08-238469

7. Robertson MJ. Role of chemokines in the biology of natural killer cells. $J$ Leukoc Biol. (2002) 71:173-83. doi: 10.1189/jlb.71.2.173

8. Cooper MA, Fehniger TA, Caligiuri MA. The biology of human natural killer-cell subsets. Trends Immunol. (2001) 22:633-40. doi: 10.1016/S1471-4906(01)02060-9

9. Martin-Fontecha A, Thomsen LL, Brett S, Gerard C, Lipp M, Lanzavecchia A, et al. Induced recruitment of NK cells to lymph nodes provides IFN-gamma for $\mathrm{T}(\mathrm{H}) 1$ priming. Nat Immunol. (2004) 5:1260-5. doi: 10.1038/ni1138

10. Street SE, Cretney E, Smyth MJ. Perforin and interferon-gamma activities independently control tumor initiation, growth, and metastasis. Blood. (2001) 97:192-7. doi: 10.1182/blood.V97.1.192

11. Smyth MJ, Thia KY, Street SE, MacGregor D, Godfrey DI, Trapani JA. Perforin-mediated cytotoxicity is critical for surveillance of spontaneous lymphoma. J Exp Med. (2000) 192:755-60. doi: 10.1084/jem.192.5.755

12. Gorelik E, Wiltrout RH, Okumura K, Habu S, Herberman RB. Role of NK cells in the control of metastatic spread and growth of tumor cells in mice. Int J Cancer. (1982) 30:107-12. doi: 10.1002/ijc.2910300118

13. Hsia JY, Chen JT, Chen CY, Hsu CP, Miaw J, Huang YS, Yang CY. Prognostic significance of intratumoral natural killer cells in primary resected esophageal squamous cell carcinoma. Chang Gung Med J. (2005) 28:335-40.

14. Villegas FR, Coca S, Villarrubia VG, Jimenez R, Chillon MJ, Jareno J, et al. Prognostic significance of tumor infiltrating natural killer cells subset CD57 in patients with squamous cell lung cancer. Lung Cancer. (2002) 35:23-8. doi: 10.1016/S0169-5002(01)00292-6

15. Ishigami S, Natsugoe S, Tokuda K, Nakajo A, Xiangming C, Iwashige $\mathrm{H}$, et al. Clinical impact of intratumoral natural killer cell and dendritic cell infiltration in gastric cancer. Cancer Lett. (2000) 159:103-8. doi: 10.1016/S0304-3835(00)00542-5

16. Coca S, Perez-Piqueras J, Martinez D, Colmenarejo A, Saez MA, Vallejo $\mathrm{C}$, et al. The prognostic significance of intratumoral natural killer cells in the CNB TEM facility, and CNB animal services for their technical support. The authors are also grateful to O. Shaw for editorial assistance.

\section{SUPPLEMENTARY MATERIAL}

The Supplementary Material for this article can be found online at: https://www.frontiersin.org/articles/10.3389/fimmu. 2019.02073/full\#supplementary-material patients with colorectal carcinoma. Cancer. (1997) 79:2320-8. doi: 10.1002/ (SICI)1097-0142(19970615)79:12<2320::AID-CNCR5>3.0.CO;2-P

17. Imai K, Matsuyama S, Miyake S, Suga K, Nakachi K. Natural cytotoxic activity of peripheral-blood lymphocytes and cancer incidence: an 11years follow-up study of a general population. Lancet. (2000) 356:1795-9. doi: 10.1016/S0140-6736(00)03231-1

18. Ruggeri L, Mancusi A, Burchielli E, Aversa F, Martelli MF, Velardi A. Natural killer cell alloreactivity and haplo-identical hematopoietic transplantation. Cytotherapy. (2006) 8:554-8. doi: 10.1080/14653240601078721

19. Miller JS, Soignier Y, Panoskaltsis-Mortari A, McNearney SA, Yun GH, Fautsch SK, et al. Successful adoptive transfer and in vivo expansion of human haploidentical NK cells in patients with cancer. Blood. (2005) 105:3051-7. doi: 10.1182/blood-2004-07-2974

20. Mehta RS, Shpall EJ, Rezvani K. Cord blood as a source of natural killer cells. Front Med. (2015) 2:93. doi: 10.3389/fmed.2015.00093

21. Knorr DA, Ni Z, Hermanson D, Hexum MK, Bendzick L, Cooper LJ, et al. Clinical-scale derivation of natural killer cells from human pluripotent stem cells for cancer therapy. Stem Cells Transl Med. (2013) 2:274-83. doi: 10.5966/sctm.2012-0084

22. Tam YK, Martinson JA, Doligosa K, Klingemann HG. Ex vivo expansion of the highly cytotoxic human natural killer-92 cell-line under current good manufacturing practice conditions for clinical adoptive cellular immunotherapy. Cytotherapy. (2003) 5:259-72. doi: 10.1080/14653240310001523

23. Gong JH, Maki G, Klingemann HG. Characterization of a human cell line (NK-92) with phenotypical and functional characteristics of activated natural killer cells. Leukemia. (1994) 8:652-8.

24. Maki G, Klingemann HG, Martinson JA, Tam YK. Factors regulating the cytotoxic activity of the human natural killer cell line, NK-92. J Hematother Stem Cell Res. (2001) 10:369-83. doi: 10.1089/152581601750288975

25. Suck G, Branch DR, Smyth MJ, Miller RG, Vergidis J, Fahim S, et al. KHYG-1, a model for the study of enhanced natural killer cell cytotoxicity. Exp Hematol. (2005) 33:1160-71. doi: 10.1016/j.exphem.2005.06.024

26. Tonn T, Becker S, Esser R, Schwabe D, Seifried E. Cellular immunotherapy of malignancies using the clonal natural killer cell line NK-92. J Hematother Stem Cell Res. (2001) 10:535-44. doi: 10.1089/152581601525 09145

27. Yan Y, Steinherz P, Klingemann HG, Dennig D, Childs BH, McGuirk J, et al. Antileukemia activity of a natural killer cell line against human leukemias. Clin Cancer Res. (1998) 4:2859-68.

28. Klingemann HG, Wong E, Maki G. A cytotoxic NK-cell line (NK-92) for ex vivo purging of leukemia from blood. Biol Blood Marrow Transpl. (1996) 2:6875.

29. Nie W, Wei W, Zuo L, Lv C, Zhang F, Lu GH, et al. Magnetic nanoclusters armed with responsive PD-1 antibody synergistically improved adoptive T-cell therapy for solid tumors. ACS Nano. (2019) 13:1469-78. doi: 10.1021/acsnano.8b07141

30. Jang ES, Shin JH, Ren G, Park MJ, Cheng K, Chen X, et al. The manipulation of natural killer cells to target tumor sites using magnetic nanoparticles. Biomaterials. (2012) 33:5584-92. doi: 10.1016/j.biomaterials.2012.04.041

31. Klingemann HG. Cellular therapy of cancer with natural killer cellswhere do we stand? Cytotherapy. (2013) 15:1185-94. doi: 10.1016/j.jcyt.2013. 03.011 
32. Mitchell DA, Fecci PE, Sampson JH. Immunotherapy of malignant brain tumors. Immunol Rev. (2008) 222:70-100. doi: 10.1111/j.1600-065X.2008.00603.x

33. Parkhurst MR, Riley JP, Dudley ME, Rosenberg SA. Adoptive transfer of autologous natural killer cells leads to high levels of circulating natural killer cells but does not mediate tumor regression. Clin Cancer Res. (2011) 17:6287-97. doi: 10.1158/1078-0432.CCR-11-1347

34. Vivier E, Ugolini S, Blaise D, Chabannon C, Brossay L. Targeting natural killer cells and natural killer T cells in cancer. Nat Rev Immunol. (2012) 12:239-52. doi: $10.1038 /$ nri3174

35. Wendel M, Galani IE, Suri-Payer E, Cerwenka A. Natural killer cell accumulation in tumors is dependent on IFN-gamma and CXCR3 ligands. Cancer Res. (2008) 68:8437-45. doi: 10.1158/0008-5472.CAN-08-1440

36. Jin H, Qian Y, Dai Y, Qiao S, Huang C, Lu L, et al. Magnetic enrichment of dendritic cell vaccine in lymph node with fluorescent-magnetic nanoparticles enhanced cancer immunotherapy. Theranostics. (2016) 6:200014. doi: 10.7150/thno.15102

37. Tukmachev D, Lunov O, Zablotskii V, Dejneka A, Babic M, Sykova E, et al. An effective strategy of magnetic stem cell delivery for spinal cord injury therapy. Nanoscale. (2015) 7:3954-8. doi: 10.1039/C4NR05791K

38. Su H, Mou Y, An Y, Han W, Huang X, Xia G, et al. The migration of synthetic magnetic nanoparticle labeled dendritic cells into lymph nodes with optical imaging. Int J Nanomed. (2013) 8:3737-44. doi: 10.2147/IJN.S52135

39. de Chickera SN, Snir J, Willert C, Rohani R, Foley R, Foster PJ, et al. Labelling dendritic cells with SPIO has implications for their subsequent in vivo migration as assessed with cellular MRI. Contrast Media Mol Imaging. (2011) 6:314-27. doi: 10.1002/cmmi.433

40. Polyak B, Fishbein I, Chorny M, Alferiev I, Williams D, Yellen B, et al. High field gradient targeting of magnetic nanoparticle-loaded endothelial cells to the surfaces of steel stents. Proc Natl Acad Sci USA. (2008) 105:698-703. doi: 10.1073/pnas.0708338105

41. Streltsova MA, Barsov EV, Erokhina SA, Sapozhnikov AM, Kovalenko EI. Current approaches to engineering of NK cells for cancer immunotherapy. Curr Pharm Des. (2018) 24:2810-24. doi: $10.2174 / 1381612824666180829113013$

42. Schoenberg K, Trompeter HI, Uhrberg M. Delivery of DNA into natural killer cells for immunotherapy. Methods Mol Biol. (2008) 423:165-72. doi: 10.1007/978-1-59745-194-9_11

43. Sanz-Ortega L, Rojas JM, Marcos A, Portilla Y, Stein JV, Barber DF. T cells loaded with magnetic nanoparticles are retained in peripheral lymph nodes by the application of a magnetic field. J Nanobiotechnol. (2019) 17:14. doi: 10.1186/s12951-019-0440-z

44. Rezvani K, Rouce RH. The application of natural killer cell immunotherapy for the treatment of cancer. Front Immunol. (2015) 6:578. doi: 10.3389/fimmu.2015.00578

45. Li Y, Yin J, Li T, Huang S, Yan H, Leavenworth J, et al. NK cell-based cancer immunotherapy: from basic biology to clinical application. Sci China Life Sci. (2015) 58:1233-45. doi: 10.1007/s11427-015-4970-9

46. Oberoi P, Wels WS. Arming NK cells with enhanced antitumor activity: CARs and beyond. Oncoimmunology. (2013) 2:e25220. doi: 10.4161/onci.25220

47. Chen Y, You F, Jiang L, Li J, Zhu X, Bao Y, et al. Gene-modified NK-92MI cells expressing a chimeric CD16-BB-zeta or CD64-BB-zeta receptor exhibit enhanced cancer-killing ability in combination with therapeutic antibody. Oncotarget. (2017) 8:37128-39. doi: 10.18632/oncotarget.16201

48. Cheng M, Zhang J, Jiang W, Chen Y, Tian Z. Natural killer cell lines in tumor immunotherapy. Front Med. (2012) 6:56-66. doi: 10.1007/s11684-012-0177-7

49. Arai S, Meagher R, Swearingen M, Myint H, Rich E, Martinson J, et al. Infusion of the allogeneic cell line NK-92 in patients with advanced renal cell cancer or melanoma: a phase I trial. Cytotherapy. (2008) 10:625-32. doi: 10.1080/14653240802301872

50. Tam YK, Maki G, Miyagawa B, Hennemann B, Tonn T, Klingemann HG. Characterization of genetically altered, interleukin 2-independent natural killer cell lines suitable for adoptive cellular immunotherapy. Hum Gene Ther. (1999) 10:1359-73. doi: 10.1089/10430349950018030

51. Tam YK, Miyagawa B, Ho VC, Klingemann HG. Immunotherapy of malignant melanoma in a SCID mouse model using the highly cytotoxic natural killer cell line NK-92. J Hematother. (1999) 8:281-90. doi: 10.1089/106161299320316
52. Massart R. Preparation of aqueous magnetic liquids in alkaline and acidic media. J Magaz. (1981) 17:1247-8. doi: 10.1109/TMAG.1981.1061188

53. Luengo Y, Nardecchia S, Morales MP, Serrano MC. Different cell responses induced by exposure to maghemite nanoparticles. Nanoscale. (2013) 5:1142837. doi: $10.1039 / \mathrm{c} 3 \mathrm{nr} 02148 \mathrm{c}$

54. Rojas JM, Sanz-Ortega L, Mulens-Arias V, Gutierrez L, Perez-Yague S, Barber DF. Superparamagnetic iron oxide nanoparticle uptake alters M2 macrophage phenotype, iron metabolism, migration, and invasion. Nanomedicine. (2016) 12:1127-38. doi: 10.1016/j.nano.2015.11.020

55. Vosshenrich CA, Samson-Villeger SI, Di Santo JP. Distinguishing features of developing natural killer cells. Curr Opin Immunol. (2005) 17:151-8. doi: 10.1016/j.coi.2005.01.005

56. Lanier LL. NK cell recognition. Annu Rev Immunol. (2005) 23:225-74. doi: 10.1146/annurev.immunol.23.021704.115526

57. Hendrickx A, Bossuyt X. Quantification of the leukocyte common antigen (CD45) in mature B-cell malignancies. Cytometry. (2001) 46:336-9. doi: $10.1002 /$ cyto. 10032

58. Sottile R, Federico G, Garofalo C, Tallerico R, Faniello MC, Quaresima B, et al. Iron and ferritin modulate MHC class I expression and NK cell recognition. Front Immunol. (2019) 10:224. doi: 10.3389/fimmu.2019.00224

59. Alter G, Malenfant JM, Altfeld M. CD107a as a functional marker for the identification of natural killer cell activity. J Immunol Methods. (2004) 294:1522. doi: $10.1016 /$ j.jim.2004.08.008

60. Orange JS, Harris KE, Andzelm MM, Valter MM, Geha RS, Strominger JL. The mature activating natural killer cell immunologic synapse is formed in distinct stages. Proc Natl Acad Sci USA. (2003) 100:14151-6. doi: 10.1073/pnas. 1835830100

61. Bernardini G, Sciume G, Santoni A. Differential chemotactic receptor requirements for NK cell subset trafficking into bone marrow. Front Immunol. (2013) 4:12. doi: 10.3389/fimmu.2013.00012

62. Al-Hubeshy ZB, Coleman A, Nelson M, Goodier MR. A rapid method for assessment of natural killer cell function after multiple receptor crosslinking. J Immunol Methods. (2011) 366:52-9. doi: 10.1016/j.jim.2011.01.007

63. Bryceson YT, March ME, Ljunggren HG, Long EO. Activation, co-activation, and co-stimulation of resting human natural killer cells. Immunol Rev. (2006) 214:73-91. doi: 10.1111/j.1600-065X.2006.00457.x

64. Chavakis E, Choi EY, Chavakis T. Novel aspects in the regulation of the leukocyte adhesion cascade. Thromb Haemost. (2009) 102:191-7. doi: 10.1160/TH08-12-0844

65. Xu Y, Sherwood JA, Lackey KH, Qin Y, Bao Y. The responses of immune cells to iron oxide nanoparticles. J Appl Toxicol. (2016) 36:543-53. doi: $10.1002 /$ jat. 3282

66. Gaharwar US, Meena R, Rajamani P. Iron oxide nanoparticles induced cytotoxicity, oxidative stress and DNA damage in lymphocytes. J Appl Toxicol. (2017) 37:1232-44. doi: 10.1002/jat.3485

67. Zupke O, Distler E, Jurchott A, Paiphansiri U, Dass M, Thomas S, et al. Nanoparticles and antigen-specific T-cell therapeutics: a comprehensive study on uptake and release. Nanomedicine. (2015) 10:1063-76. doi: $10.2217 / \mathrm{nnm} \cdot 14.160$

68. Shah A, Dobrovolskaia MA. Immunological effects of iron oxide nanoparticles and iron-based complex drug formulations: therapeutic benefits, toxicity, mechanistic insights, and translational considerations. Nanomedicine. (2018) 14:977-90. doi: 10.1016/j.nano.2018.01.014

69. Janic B, Rad AM, Jordan EK, Iskander AS, Ali MM, Varma NR, et al. Optimization and validation of FePro cell labeling method. PLoS ONE. (2009) 4:e5873. doi: 10.1371/journal.pone.0005873

70. Iida H, Takayanagi K, Nakanishi T, Kume A, Muramatsu K, Kiyohara Y, et al. Preparation of human immune effector T cells containing iron-oxide nanoparticles. Biotechnol Bioeng. (2008) 101:1123-8. doi: 10.1002/bit.21992

71. Anderson SA, Shukaliak-Quandt J, Jordan EK, Arbab AS, Martin R, McFarland $\mathrm{H}$, et al. Magnetic resonance imaging of labeled T-cells in a mouse model of multiple sclerosis. Ann Neurol. (2004) 55:654-9. doi: 10.1002/ana.20066

72. Dodd CH, Hsu HC, Chu WJ, Yang P, Zhang HG, Mountz JD Jr, et al. Normal $\mathrm{T}$-cell response and in vivo magnetic resonance imaging of $\mathrm{T}$ cells loaded with HIV transactivator-peptide-derived superparamagnetic nanoparticles. $J$ Immunol Methods. (2001) 256:89-105. doi: 10.1016/S0022-1759(01)00433-1 
73. Smirnov P, Lavergne E, Gazeau F, Lewin M, Boissonnas A, Doan BT, et al. In vivo cellular imaging of lymphocyte trafficking by MRI: a tumor model approach to cell-based anticancer therapy. Magn Reson Med. (2006) 56:498508. doi: 10.1002/mrm.20996

74. Kircher MF, Allport JR, Graves EE, Love V, Josephson L, Lichtman AH, et al. In vivo high resolution three-dimensional imaging of antigen-specific cytotoxic T-lymphocyte trafficking to tumors. Cancer Res. (2003) 63:6838-46.

75. Galli F, Histed S, Aras O. NK cell imaging by in vitro and in vivo labelling approaches. Q J Nucl Med Mol Imaging. (2014) 58:276-83.

76. Alkins R, Burgess A, Ganguly M, Francia G, Kerbel R, Wels WS, et al. Focused ultrasound delivers targeted immune cells to metastatic brain tumors. Cancer Res. (2013) 73:1892-9. doi: 10.1158/0008-5472.CAN-12-2609

77. Mallett CL, McFadden C, Chen Y, Foster PJ. Migration of iron-labeled KHYG-1 natural killer cells to subcutaneous tumors in nude mice, as detected by magnetic resonance imaging. Cytotherapy. (2012) 14:743-51. doi: 10.3109/14653249.2012.667874

78. Meier R, Golovko D, Tavri S, Henning TD, Knopp C, Piontek G, et al. Depicting adoptive immunotherapy for prostate cancer in an animal model with magnetic resonance imaging. Magn Reson Med. (2011) 65:756-63. doi: $10.1002 / \mathrm{mrm} .22652$

79. Daldrup-Link HE, Meier R, Rudelius M, Piontek G, Piert M, Metz S, et al. In vivo tracking of genetically engineered, anti-HER2/neu directed natural killer cells to HER2/neu positive mammary tumors with magnetic resonance imaging. Eur Radiol. (2005) 15:4-13. doi: 10.1007/s00330-004-2526-7

80. Meng Y, Shi C, Hu B, Gong J, Zhong X, Lin X, et al. External magnetic field promotes homing of magnetized stem cells following subcutaneous injection. BMC Cell Biol. (2017) 18:24. doi: 10.1186/s12860-017-0140-1

81. Liao N, Wu M, Pan F, Lin J, Li Z, Zhang D, et al. Poly (dopamine) coated superparamagnetic iron oxide nanocluster for non-invasive labeling, tracking, and targeted delivery of adipose tissue-derived stem cells. Sci Rep. (2016) 6:18746. doi: 10.1038/srep18746

82. Xu Y, Wu C, Zhu W, Xia C, Wang D, Zhang $\mathrm{H}$, et al. Superparamagnetic MRI probes for in vivo tracking of dendritic cell migration with a clinical $3 \mathrm{~T}$ scanner. Biomaterials. (2015) 58:63-71. doi: 10.1016/j.biomaterials.2015.04.016

83. Billadeau DD, Upshaw JL, Schoon RA, Dick CJ, Leibson PJ. NKG2D-DAP10 triggers human NK cell-mediated killing via a Syk-independent regulatory pathway. Nat Immunol. (2003) 4:557-64. doi: 10.1038/ni929
84. Wu J, Cherwinski H, Spies T, Phillips JH, Lanier LL. DAP10 and DAP12 form distinct, but functionally cooperative, receptor complexes in natural killer cells. J Exp Med. (2000) 192:1059-68. doi: 10.1084/jem.192.7.1059

85. Masopust D, Schenkel JM. The integration of T cell migration, differentiation and function. Nat Rev Immunol. (2013) 13:309-20. doi: 10.1038/nri3442

86. Nolz JC, Starbeck-Miller GR, Harty JT. Naive, effector and memory CD8 Tcell trafficking: parallels and distinctions. Immunotherapy. (2011) 3:1223-33. doi: 10.2217/imt.11.100

87. Kyrtatos PG, Lehtolainen P, Junemann-Ramirez M, Garcia-Prieto A, Price AN, Martin JF, et al. Magnetic tagging increases delivery of circulating progenitors in vascular injury. JACC Cardiovasc Interv. (2009) 2:794-802. doi: 10.1016/j.jcin.2009.05.014

88. Arbab AS, Jordan EK, Wilson LB, Yocum GT, Lewis BK, Frank JA. In vivo trafficking and targeted delivery of magnetically labeled stem cells. Hum Gene Ther. (2004) 15:351-60. doi: 10.1089/104303404322959506

89. Landazuri N, Tong S, Suo J, Joseph G, Weiss D, Sutcliffe DJ, et al. Magnetic targeting of human mesenchymal stem cells with internalized superparamagnetic iron oxide nanoparticles. Small. (2013) 9:4017-26. doi: $10.1002 /$ smll.201300570

90. Riegler J, Wells JA, Kyrtatos PG, Price AN, Pankhurst QA, Lythgoe MF. Targeted magnetic delivery and tracking of cells using a magnetic resonance imaging system. Biomaterials. (2010) 31:5366-71. doi: 10.1016/j.biomaterials.2010.03.032

91. Muthana M, Kennerley AJ, Hughes R, Fagnano E, Richardson J, Paul M, et al. Directing cell therapy to anatomic target sites in vivo with magnetic resonance targeting. Nat Commun. (2015) 6:8009. doi: 10.1038/ncomms9009

Conflict of Interest Statement: The authors declare that the research was conducted in the absence of any commercial or financial relationships that could be construed as a potential conflict of interest.

Copyright (C) 2019 Sanz-Ortega, Rojas, Portilla, Pérez-Yagüe and Barber. This is an open-access article distributed under the terms of the Creative Commons Attribution License (CC BY). The use, distribution or reproduction in other forums is permitted, provided the original author(s) and the copyright owner(s) are credited and that the original publication in this journal is cited, in accordance with accepted academic practice. No use, distribution or reproduction is permitted which does not comply with these terms. 